\title{
LONG-TERM ABANDONMENT OF MOUNTAIN MEADOWS AFFECTS BUMBLEBEES, TRUE BUGS AND GRASSHOPPERS: A CASE STUDY IN THE AUSTRIAN ALPS
}

\author{
WALCHER, R. ${ }^{1 *}$ - HUSSAIN, R. I. ${ }^{1}-$ SACHSLEHNER, L. ${ }^{2}-$ BOHNER, A. ${ }^{3}-$ JERNEJ, I. ${ }^{1}-$

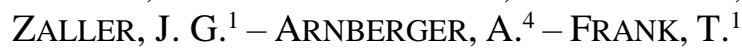 \\ ${ }^{1}$ Institute of Zoology, University of Natural Resources and Life Sciences Vienna \\ Gregor-Mendel-Straße 33, A-1180 Vienna, Austria \\ ${ }^{2}$ Büro für Naturschutzpraxis und Forschung, An der Scheibenwiese 1/1/2 \\ A-1160 Vienna, Austria \\ ${ }^{3}$ Agricultural Research and Education Centre Raumberg-Gumpenstein \\ Raumberg 38, A-8952 Irdning Donnersbachtal, Austria
}

${ }^{4}$ Institute for Landscape Development, Recreation and Conservation Planning, University of Natural Resources and Life Sciences Vienna, Peter-Jordan-Straße 65, A-1180 Vienna, Austria

"Corresponding author

e-mail: ronnie.walcher@boku.ac.at,ronnie.walcher@gmx.at; phone: +43/1/47654-83315

(Received $16^{\text {th }}$ Jan 2019; accepted $28^{\text {th }}$ Feb 2019)

\begin{abstract}
We investigated how abandonment of mountain meadows influences bumblebees, true bugs and grasshoppers in two years in the Eisenwurzen region (Austria). We surveyed abandoned (20-40 years old) and annually mown unfertilized meadows. Bumblebees were observed in $20 \mathrm{~m}^{2}$ plots, bugs were collected by sweep netting and grasshoppers identified with a soundscape approach. The insect groups were analysed in relation to plant species richness, flower cover, vegetation cover and the surrounding landscape. Bumblebee species richness and richness of long-tongued species were significantly higher in managed meadows. Similarly, we found significantly more phytophagous bug species in managed meadows, whereas grasshoppers showed no difference between meadow types. Bumblebee species richness and abundance, the abundance of phytophagous bugs and total grasshopper species richness were associated with total flower cover. Surrounding forest area negatively affected bugs, while open landscape positively affected bugs, both regarding species richness and abundance, number of phytophagous species and individuals and individuals overwintering as egg. Species assemblages of the three insect groups did not significantly differ between meadow types. Extensive management is important to preserve bumblebee and bug richness. However, abandoned meadows, which are not yet regrown into forest can still act as suitable habitats for the three insect groups.
\end{abstract}

Keywords: extensive management, management cessation, grasslands, Bombus sp., Heteroptera, Orthoptera

\section{Introduction}

More than $40 \%$ of the earth's terrestrial surface is covered by grasslands (Suttie et al., 2005). In Central European landscapes, they represent valuable ecosystems harbouring a high plant diversity (Dengler et al., 2013; Chytrý et al., 2015). Seminatural grasslands were maintained for hundreds of years by local farmers and traditional land-use systems (Maurer et al., 2006; Fischer et al., 2008; Poschlod et al., 2009; Hejcman et al., 2013; Price et al., 2015). In Austria, 60\% of the agriculturally used area is made up of grasslands, $90 \%$ of which are not ploughed for at least 20 years (Pötsch et al., 2005). Changes in farming practice and intensity have led to a reduction 
of semi-natural grasslands throughout European landscapes (Wesche et al., 2012). Main causes of this reduction are agricultural intensification and abandonment (e.g. Strijker, 2005; Baur et al., 2006a; Gellrich et al., 2007; Tasser et al., 2007; Prévosto et al., 2011; Graf et al., 2014). The reasons for the abandonment of extensively managed mountain meadows are manifold. Rey Benayas et al. (2007) identified some of the main drivers of land-use abandonment and mentioned socio-economic factors like rural depopulation and ecological factors like slope, altitude and accessibility as factors for management cessation. Especially, slopes with a high inclination are more often abandoned (Tasser et al., 2007; Niedrist et al., 2009). Land-use abandonment, and the consequent process of secondary succession (Komac et al., 2013), leads to forest-regrowth (Gellrich et al., 2007; Prévosto et al., 2011). Abandoned meadows undergo several successional stages (Tasser et al., 2007). Some of these stages remain stable for decades and abandoned grassland remains open for a long time (Walcher et al., 2017). Usually, regular mowing or grazing is necessary to maintain semi-natural grasslands without encroachment of woody vegetation (Hannson and Fogelfors, 2000; Maurer et al., 2006).

While there is a great body of evidence regarding the effects of abandonment on plants, knowledge regarding insect species is scarce. The effects of human-induced land-use changes strongly depend on the insect taxa being considered (Bonari et al., 2017; Lessard-Therrien et al., 2018). Therefore, studies taking different insect groups into account, are important in order to understand the consequences of management measures and to develop conservation strategies (Van Noordwijk et al., 2017).

The three insect groups investigated in the present study are scarcely studied in mountainous grasslands, and especially data on true bugs in mountainous grassland ecosystems are largely missing. This is surprising because bumblebees, bugs and grasshoppers are suitable organisms to study the effects of land-use abandonment in grassland ecosystems. The reduction of foraging resources and loss of suitable nesting sites are the main causes for bumblebee decline (Carvell, 2002; Goulson et al., 2005; Carvell et al., 2006; Nieto et al., 2014; Goulson et al., 2015). Long-tongued bumblebee species, in particular, often have specialized diets and are known to be in decline in many European countries (Goulson et al., 2005; Kosior et al., 2007). The true bugs are a diverse group, including generalist and specialist species, which are assumed to react differently to land-use changes such as abandonment. Along with grasshoppers, they respond sensitively to altered environmental conditions (Schwab et al., 2002; Frank and Kuenzle, 2006; Fartmann et al., 2012) and are suitable indicators for land-use changes (Duelli and Obrist, 2003; Fartmann et al., 2012). Especially, grasshoppers require specific habitat conditions (Baur et al., 2006b). They are particularly affected by the cessation of management (e.g. Marini et al., 2009; Uchida et al., 2016).

In the present study, we aimed at investigating how abandonment impacts richness and abundance of bumblebees, true bugs and grasshoppers. Therefore, we compared extensively managed annually mown meadows (no fertilizer application) with abandoned meadows in an Austrian region. The Eisenwurzen region is one of the largest nature reserve areas in Austria. This area contains a range of semi-natural habitats and is facing severe challenges due to abandonment (Haberl, 2009). We investigated the three insect taxa for the same reasons as in Walcher et al. (2017), but collected an additional year of data and one additional meadow per treatment. Data sampling over multiple years in mountainous grassland ecosystems is highly important in order to possibly give recommendations for management schemes and conservation strategies in the future. Thus, in the present study, we picked up the highly topical issue 
of land-use abandonment by conducting a 2-years research in such an important nature reserve area.

We hypothesized that (i) species richness and assemblages of the three insect groups differ significantly between meadow types and, (ii) surrounding landscape structure and vegetation parameters significantly influence the three insect groups.

\section{Methods}

\section{Study region}

The study was carried out in 2015 and 2016 in the Styrian part of the Eisenwurzen region (Austria). Sampling was carried out once in June (between $16^{\text {th }}$ and $18^{\text {th }}$ of June) and once in August (between $16^{\text {th }}$ and $18^{\text {th }}$ of August) in both years. The mean annual temperature in this region is $6.9^{\circ} \mathrm{C}$ and the mean annual precipitation is $1087 \mathrm{~mm}$. Eight southerly exposed meadows - four extensively managed and four abandoned were selected in the three municipalities St. Gallen, Stainach, and Pürgg (Fig. 1, Table 1).

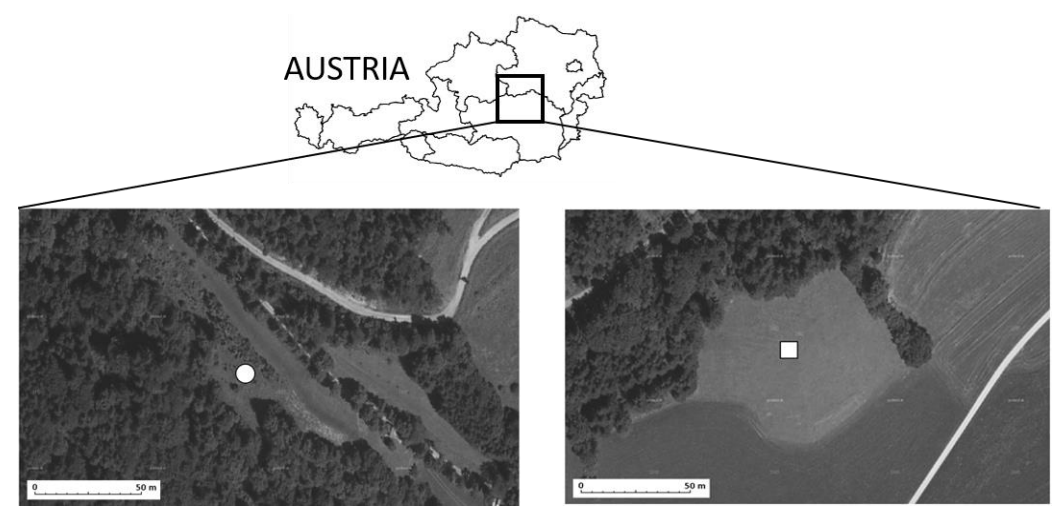

Figure 1. Location of the study region Eisenwurzen. Orthophotos are shown for one abandoned (०) and one managed meadow () (data source: www.basemap.at)

Table 1. Coordinates of the investigated meadows in the Eisenwurzen region. Meadow AlA4 are abandoned and meadows M1-M4 are managed meadows

\begin{tabular}{c|c|c}
\hline Meadow & Latitude & Longitude \\
\hline A1 & $47^{\circ} 40^{\prime} 03.8^{\prime \prime} \mathrm{N}$ & $14^{\circ} 35^{\prime} 43.9^{\prime \prime} \mathrm{E}$ \\
A2 & $47^{\circ} 39^{\prime} 51.5^{\prime \prime} \mathrm{N}$ & $14^{\circ} 35^{\prime} 39.6^{\prime \prime} \mathrm{E}$ \\
A3 & $47^{\circ} 31^{\prime} 46.2^{\prime \prime} \mathrm{N}$ & $14^{\circ} 04^{\prime} 23.8^{\prime \prime} \mathrm{E}$ \\
A4 & $47^{\circ} 31^{\prime} 01.1^{\prime \prime} \mathrm{N}$ & $14^{\circ} 07^{\prime} 26.9^{\prime \prime} \mathrm{E}$ \\
M1 & $47^{\circ} 40^{\prime} 06.2^{\prime \prime} \mathrm{N}$ & $14^{\circ} 35^{\prime} 48.8^{\prime \prime} \mathrm{E}$ \\
M2 & $47^{\circ} 39^{\prime} 53.3^{\prime \prime} \mathrm{N}$ & $14^{\circ} 35^{\prime} 42.7^{\prime \prime} \mathrm{E}$ \\
M3 & $47^{\circ} 31^{\prime} 45.6^{\prime \prime} \mathrm{N}$ & $14^{\circ} 04^{\prime} 27.0^{\prime \prime} \mathrm{E}$ \\
M4 & $47^{\circ} 31^{\prime} 01.8^{\prime \prime} \mathrm{N}$ & $14^{\circ} 07^{\prime} 31.4^{\prime \prime} \mathrm{E}$ \\
\hline
\end{tabular}

Photos of the studied meadows give an impression of managed (Fig $2 a$ and $b$ ) and abandoned (Fig $2 c$ and $d$ ) meadows.

Due to technical problems with the soundscape method, we could only survey grasshoppers in three managed and three abandoned meadows, making a total of six meadows $(n=6)$. The annually mown, non-fertilized managed meadows are usually 
mown at the beginning of August. In both years, 2015 and 2016, the meadows were mown mid-July. Thus, sampling in August took place four weeks after the last cut, thus ensuring new plants in flower for the second sampling round in August. Meadows are usually mown manually with bar mowers or, on very steep parts of the meadows, using a scythe. Abandoned meadows are between 20 and 40 years old and were used extensively before cessation of management. Information about former and current management of the investigated meadows and age of abandoned meadows was gathered by interviewing the land owners. The meadows were located at an average elevation of $670 \mathrm{~m}$ above sea level. The size of managed meadows ranged from 1095 to $4500 \mathrm{~m}^{2}$, while the size of abandoned meadows ranged from 573 to $3370 \mathrm{~m}^{2}$. The sizes of managed and abandoned meadows were not significantly different $(\mathrm{F}=0.959, \mathrm{p}=0.365$; ANOVA). We measured the percentage of surrounding open landscape (pastures, extensively and intensively used meadows) and the percentage of forest cover (closed forest) within a $500 \mathrm{~m}$ radius around the centre of each meadow, using ArcGIS (orthophotos, updated in 2017, ArcGIS basemap).
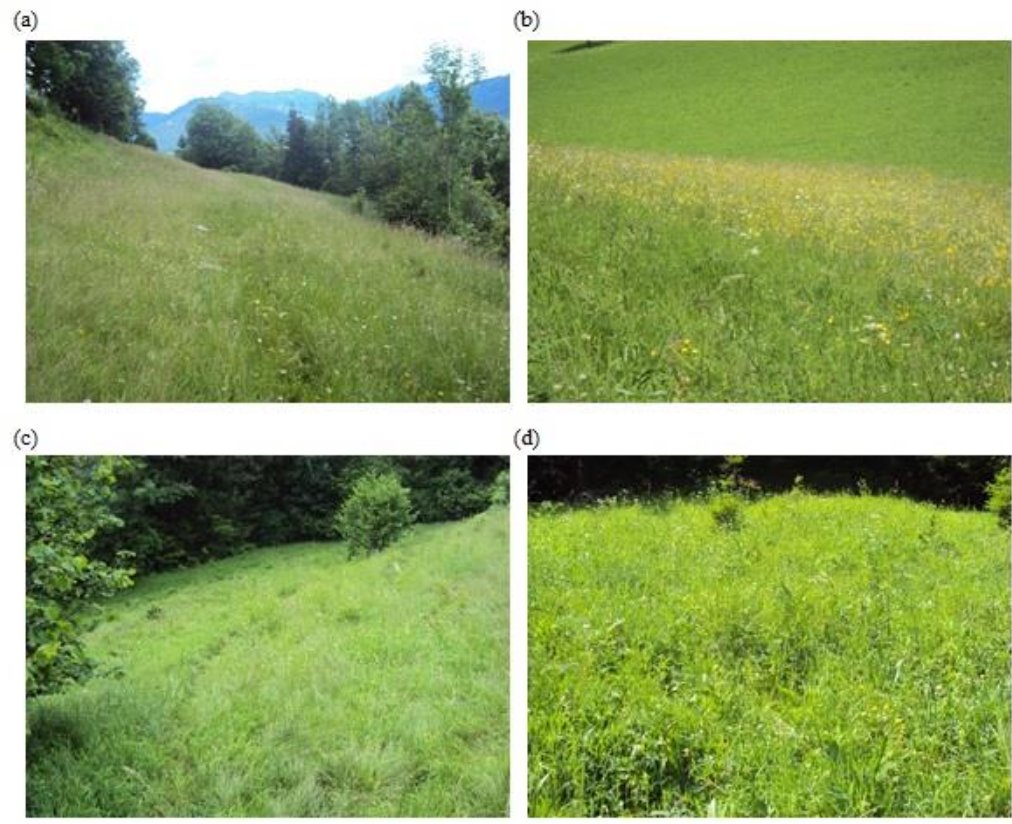

Figure 2. Photos of study sites in the Eisenwurzen region ( $a$ and $b$ are managed and $c$ and $d$ are abandoned meadows), Photos (C) R. Walcher

\section{Insect sampling}

We sampled bumblebees and bugs in June and August 2015 and 2016 and grasshoppers in August 2015 and 2016. We assessed richness and abundance of bumblebees in four rectangular $20 \mathrm{~m}^{2}(4 * 5)$ plots at each meadow. Sampling plots were selected randomly in the centre of the meadows. In order to guarantee standardisation of the sampling method, we selected distances of 3, 9 and 27 meters between the plots. Sampling was performed for 15 minutes per plot, summing up to 1 hour of observation time, and individual bumblebees were counted and identified onsite at the species level using an identification key by Gokcezade et al. (2015). However, single individuals had to be collected for complete confident identification in 
the lab. Furthermore, we grouped bumblebees into long- and short-tongued species and individuals. This classification is important because tongue length plays a major role in food plant selection.

For true bug sampling we carried out sweep-netting along defined transects. The distance between two transects was 15 metre. Specifically, we conducted 90 sweeps per meadow subdivided into $3 * 30$ sweeps covering an area of total $90 \mathrm{~m}^{2}$ (3 transects of 15 metre length $* 2 \mathrm{~m}$ width of the transect). Collected bugs were identified using identification literature of Wagner $(1952,1966,1967)$ and Strauss $(2010)$. We gathered information on food preference (zoo- and phytophagous) and overwintering strategy (overwintering as egg or imagoes) from Wagner (1952, 1966, 1967).

To assess number of grasshopper species, we used digital recorders (Olympus LS-12, Olympus Europa SE \& CO. KG, Hamburg, Germany) and connected them to bat detectors (Batbox III D, Batbox Ltd. Steyning, UK). We adjusted a frequency of $27 \mathrm{kHz}$ on the detectors with a bandwidth of $16 \mathrm{kHz}$. We installed both devices on $80 \mathrm{~cm}$ high platforms. The records, which were conducted between 10 a.m. and 5 p.m., were afterwards analysed at the office by comparing them with acoustic material (e.g. Roesti and Keist, 2009). The recording range was approximately 30 meters. No analysis of grasshopper abundance can be made with the soundscape approach. All identified grasshoppers were assigned to Ensifera and Caelifera according to Baur et al. (2006b). All samples were taken during suitable weather conditions (low wind, sunny conditions, temperatures above $20^{\circ} \mathrm{C}$, dry vegetation).

For bumblebee and true bug sampling, we carried out sampling in the meadows successively and not parallel. However, to avoid that the meadows were always sampled at the same time of the day, we investigated meadows, which were sampled in June in the morning, in August in the afternoon 2015. In the following year (2016) we sampled the meadows vice versa to 2015. A sketch showing the experimental setup of insect sampling is shown in Figure 3.

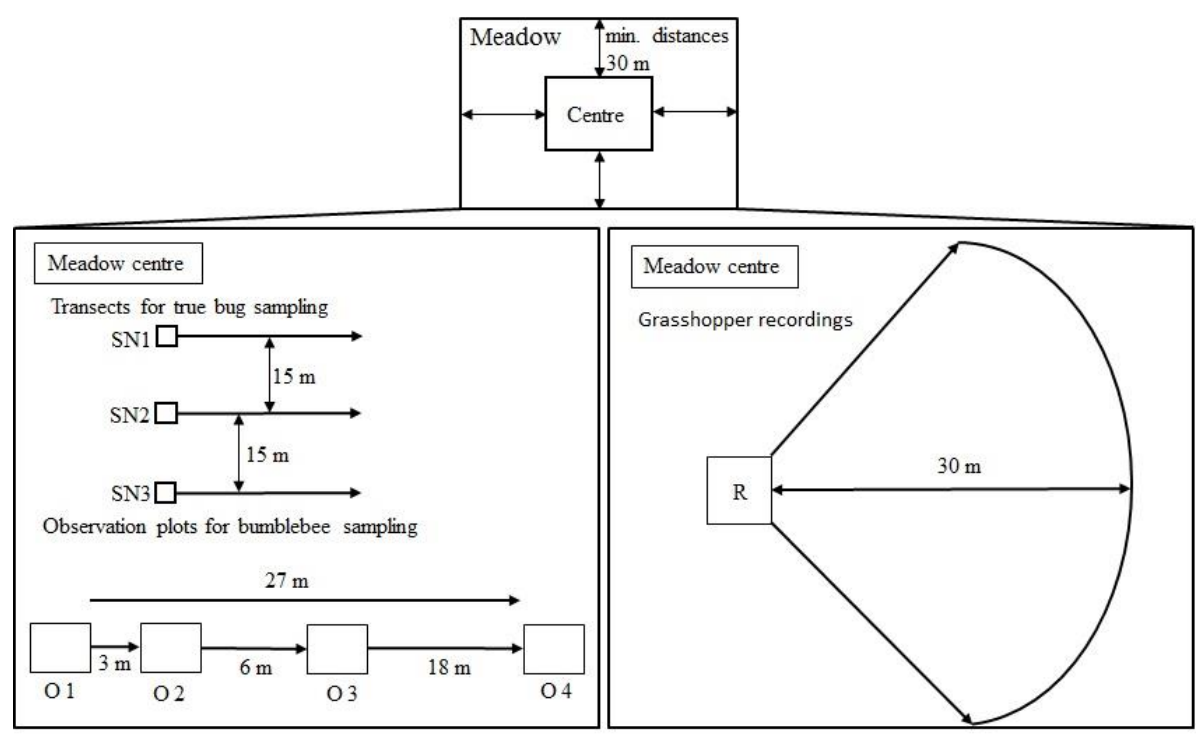

Figure 3. Sketch showing sampling locations within one meadow. SN1-SN3 denotes transects for sweep sampling of true bugs. O1-O4 denotes observation plots for bumblebees. $R$ denotes location of the recording devices. Measurements were carried out in the centre of each meadow keeping distances of minimum 30 meter to adjacent habitats 


\section{Plant sampling}

To estimate the influence of vegetation parameters on the three insect groups, we examined vegetation cover as well as total flower cover and diversity of vascular plants in each meadow. Sampling was carried out in June and August 2015 and 2016. We selected four $1 \mathrm{~m}^{2}$ plots in the centre of the meadows. For the purpose of vegetation assessments, we placed a $1 * 1 \mathrm{~m}$ frame on the ground and identified each plant to the species level. We recorded percentage of vegetation cover (including living biomass, necromass and open soil) and percentage of flower cover within the total plot area (1 $\mathrm{m}^{2}$ ). We subdivided individual plant species into plant species providing open or hidden nectar flowers, which is an especially important vegetation parameter for bumblebees and their different tongue-length.

\section{Statistical analysis}

We used Shapiro-tests to check for normal distribution, and Bartlett- and Fligner-tests to check for homogeneity of variances of the data. We used generalized linear mixed models (GLMMs) to investigate the management effect on species richness and abundance of the three insect groups. Management was chosen as a fixed factor, and month (June and August) and year (2015 and 2016) as random factors. We investigated overdispersion in GLMMs by including an observation-level random effect (Harrison, 2014; Meyer et al., 2017). GLMMs were performed using the R-package lme4 (Bates et al., 2015). We conducted generalized linear models (GLMs) to investigate differences between management types regarding tongue-length of bumblebees, feeding and hibernating strategy types of true bugs, suborders of grasshoppers, effects of vegetation parameters (vegetation and flower cover, plant species richness, plants providing hidden and open nectar flowers) and the structure of the surrounding landscape (open landscape and forest) on the three investigated insect groups. To test for over- or underdispersion, we used the $P_{\text {__disp }}()$ function (R-package "msme" version 0.5.1, Hilbe and Robinson, 2014) and the dispersion.test() function in $\mathrm{R}$ (R-package “AER", version 1.2-4, Kleiber et al., 2015). We specified quasi-poisson errors to correct for over- or underdispersion in GLMs (Crawley, 2013). Before calculating GLM models, we investigated possible correlations between plant parameters and surrounding landscape structures. Since plant parameters and surrounding landscape structures were correlated, we decided to test them in single GLM-models. Furthermore, the point-biserial correlation coefficient $\mathbf{r}_{p b}$ was computed to detect possible significant associations of any individual species of the three insect groups with the two meadow types. This procedure calculates the strength (R-function strassoc()) and significance (R-function signassoc()) of possible associations. Both functions are included in the package "indicspecies" version 1.7.5 in R (De Cáceres and Jansen, 2015). Two-sided permutation tests were conducted to assess significant associations. We calculated confidence intervals and bootstrapped data 999 times with replacement (Walcher et al., 2017).

We analysed possible differences in species composition of the three insect groups conducting a principal coordinate analysis (PCO). We included month and year as random factors, similar to the univariate analysis. A permutational ANOVA (PERMANOVA) was conducted to evaluate significant differences in species assemblages of the three insect groups. We permuted residuals 9999 times under a reduced model. Furthermore, by conducting the SIMPER-routine (similarity 
percentages), we investigated how individual species contribute to the differences between meadow types.

We used the version 6.1.13 of the software Primer including PERMANOVA+ (PRIMER-E Ltd. Plymouth, UK) to conduct PCO, PERMANOVA, and SIMPER routines. We performed all other statistical analysis in R, version 3.1.3 (R Core Team, 2015).

\section{Results}

\section{Bumblebees}

In total, we collected 98 bumblebee individuals of 13 species (Bombus sp., Appendix A). Twelve species with 64 individuals were found in managed, and 8 species with 34 individuals in abandoned meadows. We identified three cuckoo bumblebees (Bombus [Psithyrus] sp.). Further, we distinguished between 5 long- and 8 shorttongued species.

Managed meadows harboured a significantly higher total bumblebee richness and higher numbers of long-tongued species (GLMM, $\mathrm{z}=2.479, \mathrm{p}=0.0132$ and $\mathrm{z}=2.147$, $\mathrm{p}=0.0318$ respectively; Fig. $4 a$ and $b$ ).

(a)

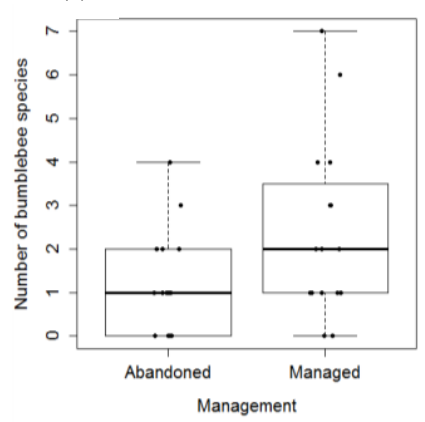

(b)

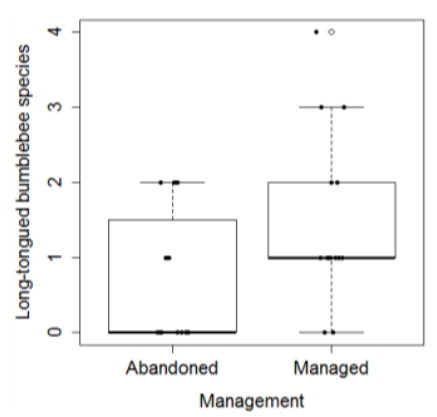

(c)

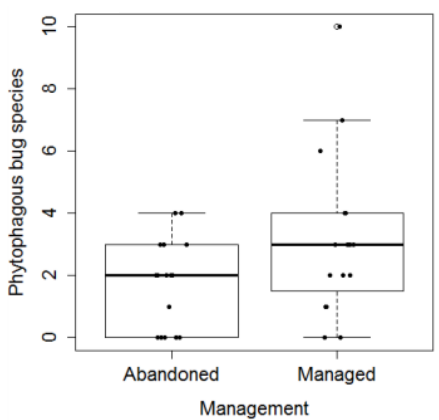

Figure 4. Response of (a) total bumblebee species richness, (b) long-tongued bumblebee species richness and (c) phytophagous bug species richness on management. Boxplots show the median and the $25 \%$ and $75 \%$ percentiles. The dashed lines indicate the $10 \%$ and $90 \%$ percentiles. Outliers are indicated by (०). Data points are included as jitter-overlay

Higher total flower cover increased total bumblebee species richness and abundance, and both number of short- and long-tongued species and individuals (Table 2, Fig. 5a-f).

Higher plant species with hidden nectar flowers significantly increased total bumblebee species richness as well as number of long-tongued species (Table 2, Fig. $6 a$ and $b$ ).

No relationship was found between number of bumblebee species and individuals, abundance of short-and long-tongued species and individuals and total plant species richness, surrounding landscape (open landscape and forest cover), vegetation cover and number of plant species with open nectar flowers. The point-biserial correlation did not show a significant association between individual bumblebee species and meadow types.

There was no significant difference between meadow types regarding bumblebee species assemblages (PERMANOVA, main-test: $\mathrm{p}=0.145$ ). We found an average 
similarity of 15.30 in annually mown meadows (SIMPER-analysis). $92.17 \%$ of the similarity was described by B. lapidarius, B. hortorum, B. humilis and B. terrestris. Bombus humilis, B. pascuorum, B. hypnorum and B. terrestris explained $91.42 \%$ of the similarity of 7.22 in abandoned meadows. Both meadow types revealed a dissimilarity of 91.49. Bombus humilis, B. hortorum, B. lapidarius, B. pascuorum and B. terrestris described $70.34 \%$ of the dissimilarity.

Table 2. Generalized Linear Models (GLM, significance level: $p<0.05)$ showing the effects of vegetation parameters on the three insect groups. The table shows the relationships between flower classes and bumblebees and the relationship between surrounding landscape structure, true bugs and grasshoppers. P-values which are significant are highlighted in bold (n.s: not significant, (-) indicates a negative effect, (+) indicates a positive effect, Res.dev. $=$ Residual deviance, $d f=$ degrees of freedom)

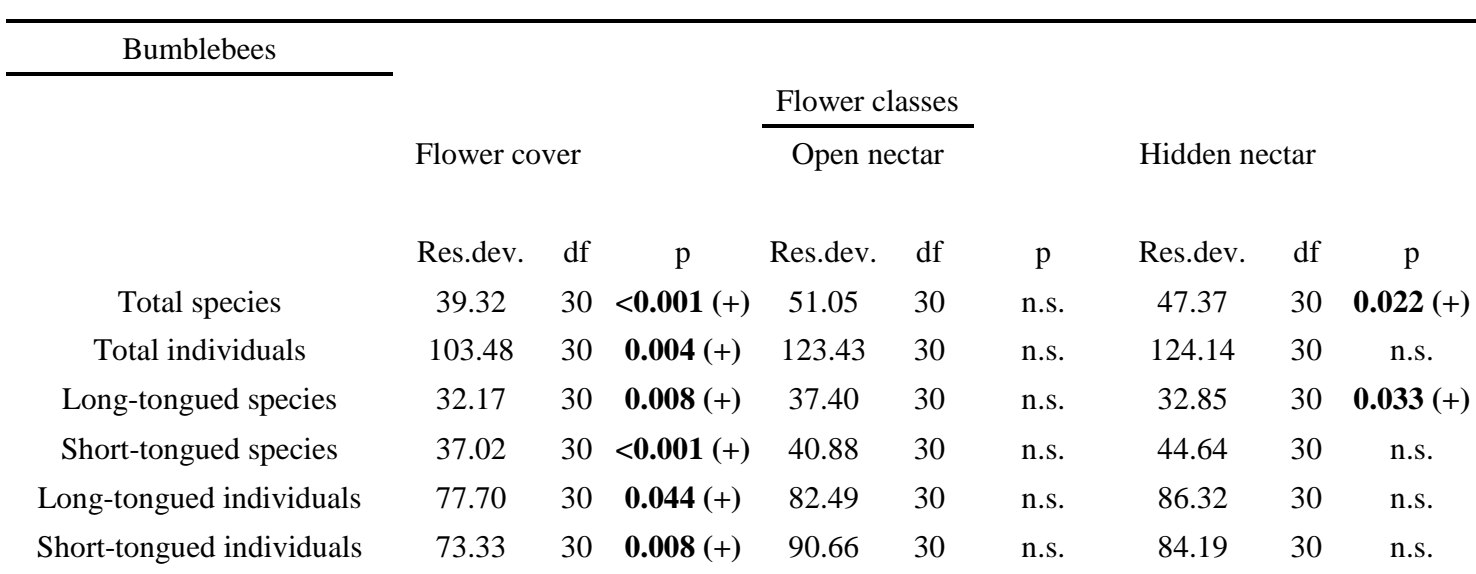

Bugs

Total species
Total individuals
Phytophagous species
Overwinter egg species
Overwinter imago species
Phytophagous individuals
Overwinter egg individuals
Overwinter imago indiv.

Flower cover

Res.dev. df

$57.73 \quad 30$

$280.76 \quad 30$

$62.66 \quad 30$

$44.03 \quad 30$

$64.30 \quad 30$

$303.24 \quad 30$

$309.44 \quad 30$

$122.18 \quad 30$

$\frac{\text { Surrounding landscape structure }}{\text { Open landscape }}$ Forest cover

$\begin{array}{ccc}\text { p } & \text { Res.dev. } & \text { df } \\ \text { n.s. } & 57.26 & 30 \\ \text { n.s. } & 273.40 & 30 \\ \text { n.s. } & 60.41 & 30 \\ \text { n.s. } & 43.47 & 30 \\ \text { n.s. } & 65.08 & 30 \\ \text {.048 (+) } & 289.55 & 30 \\ \text { n.s. } & 290.30 & 30 \\ \text { n.s. } & 123.65 & 30\end{array}$

$\begin{array}{cccc}\mathrm{p} & \text { Res.dev. } & \mathrm{df} & \mathrm{p} \\ \text { n.s. } & 54.69 & 30 & \mathbf{0 . 0 3 4}(-) \\ \mathbf{0 . 0 4 9}(+) & 247.04 & 30 & \mathbf{0 . 0 1 1}(-) \\ \mathbf{0 . 0 3 5}(+) & 56.72 & 30 & \mathbf{0 . 0 0 4}(-) \\ \text { n.s. } & 42.93 & 30 & \text { n.s. } \\ \text { n.s. } & 62.92 & 30 & \text { n.s. } \\ \mathbf{0 . 0 3 2}(+) & 258.92 & 30 & \mathbf{0 . 0 0 7}(-) \\ \mathbf{0 . 0 2 6}(+) & 262.88 & 30 & \mathbf{0 . 0 0 8}(-) \\ \text { n.s. } & 122.32 & 30 & \text { n.s. }\end{array}$

Grasshoppers

Flower cover

Surrounding landscape structure

Open landscape $\quad$ Forest cover

\begin{tabular}{cccccccccc} 
& Res.dev. & $\mathrm{df}$ & $\mathrm{p}$ & Res.dev. & $\mathrm{df}$ & $\mathrm{p}$ & Res.dev. & $\mathrm{df}$ & $\mathrm{p}$ \\
Total species & 1.95 & 10 & $\mathbf{0 . 0 0 9}(+)$ & 3.72 & 10 & n.s. & 3.76 & 10 & n.s. \\
Caelifera & 2.52 & 10 & n.s. & 1.99 & 10 & n.s. & 1.74 & 10 & $\mathbf{0 . 0 4 6}(-)$ \\
Ensifera & 7.15 & 10 & n.s. & 7.82 & 10 & n.s. & 7.67 & 10 & n.s. \\
\hline
\end{tabular}




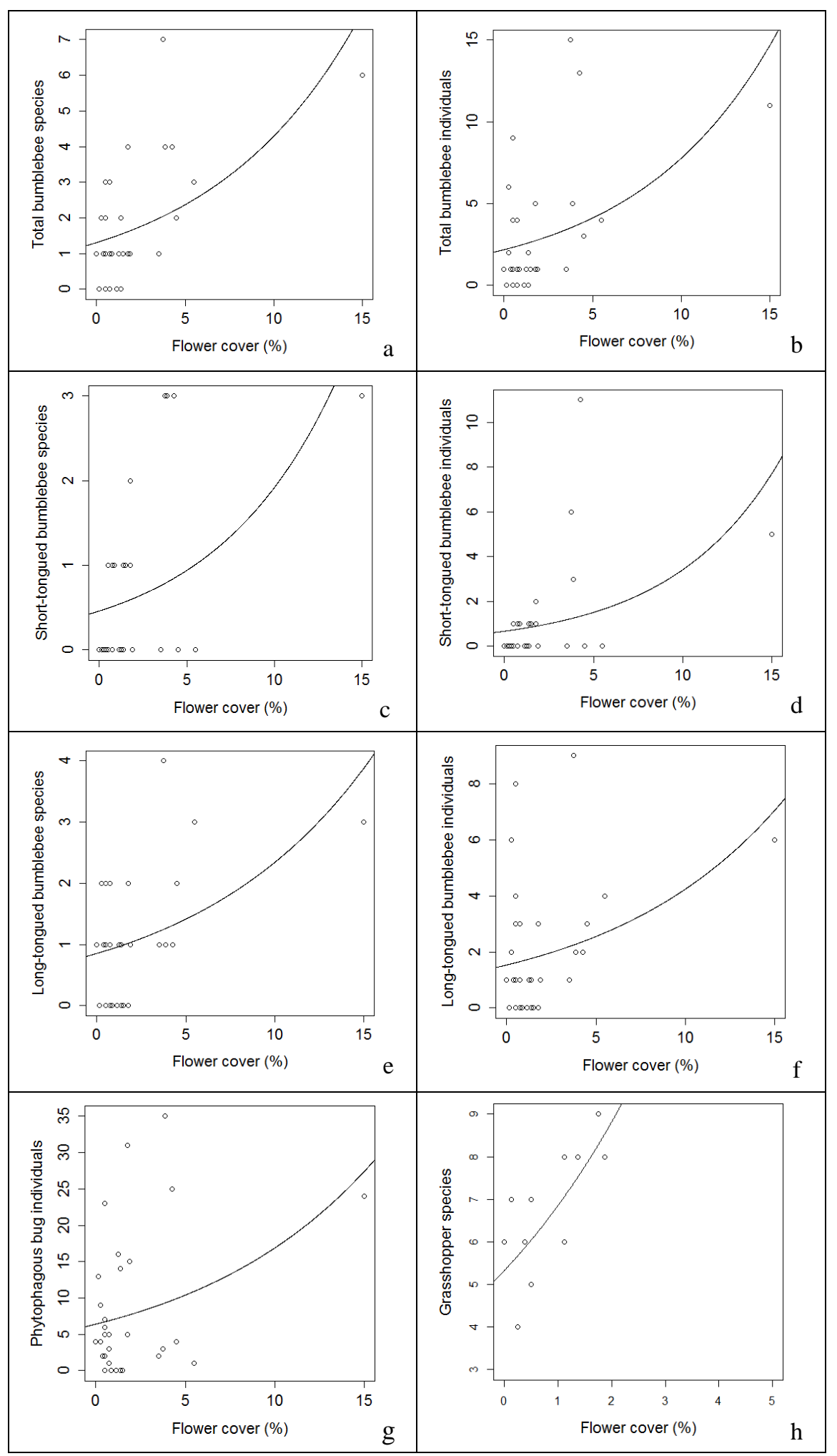

Figure 5. Relationship between flower cover (in \%) and (a) total bumblebee species, (b) total bumblebee abundance, (c) short-tongued bumblebee species, (d) short-tongued bumblebee abundance, (e) long-tongued bumblebee species, $(f)$ long-tongued bumblebee abundance, $(g)$ abundance of phytophagous bugs and ( $h$ ) total grasshopper species. Fitted lines were drawn through the scatterplot using the predict-function in $R$ 


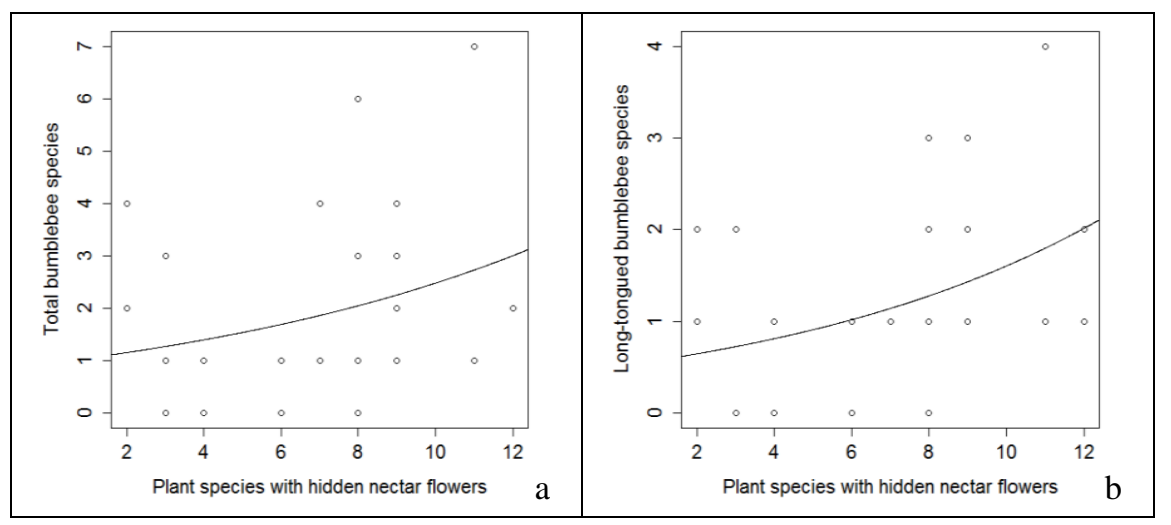

Figure 6. Relationship between plant species with hidden nectar flowers and (a) total bumblebee species and (b) long-tongued bumblebee species. Fitted lines were drawn through the scatterplot using the predict-function in $R$

\section{True bugs}

In total, we found 281 bug individuals of 32 species (Appendix B). We found 165 individuals of 27 species in managed, and 116 individuals of 13 species in abandoned meadows. Twenty-nine species were classified as phytophagous and three species as zoophagous. We classified 12 species as overwintering as eggs and 20 species as overwintering as imagos. We did not further include zoophagous bug species in the analysis due to the underrepresentation of this trophic group.

Managed meadows harboured significantly higher phytophagous bug species than abandoned meadows (GLMM, z=1.970, $\mathrm{p}=0.0488$; Fig. 4c). Richness and abundance of true bugs, number of phytophagous bug species and individuals and individuals hibernating as eggs decreased with an increasing amount of forest cover in the surrounding landscape (Table 2). A larger proportion of open landscape in the surrounding landscape positively affected total number of individuals, individuals overwintering as eggs and species and individuals belonging to the phytophagous trophic group (Table 2). Increasing flower cover increased the number of phytophagous individuals (Table 2, Fig. 5g). No individual bug species was associated with either annually mown or abandoned meadows.

True bug species assemblages did not significantly differ between meadow types (PERMANOVA, main-test: $\mathrm{p}=0.565$ ). The average Bray-Curtis similarity in the SIMPER-analysis in managed meadows was 7.19, with Leptopterna dolobrata, Carpocoris purpureipennis, Orthops kalmii, Dolychoris baccarum, Graphosoma lineatum and Halticus apterus explaining $91.58 \%$ of the similarity. Abandoned meadows revealed a similarity of $9.13 .91 .11 \%$ of the similarity was due to the species Nabis rugosus, Leptoperna dolobrata, Polymerus microphtalmus and Graphosoma lineatum. We found an average dissimilarity of 92.30 between meadow types, where $62.70 \%$ of the dissimilarity was explained by the species Leptopterna dolobrata, Nabis rugosus, Halticus apterus, Polymerus microphtalmus and Carpocoris purpureipennis.

\section{Grasshoppers}

We detected a total of 15 grasshopper species in both meadow types (Appendix $C$ ). We found 12 species in managed and 13 species in abandoned meadows. We found eight Caelifera species and seven Ensifera species. 
There was no management effect on total species richness or on richness of Caelifera and Ensifera. Increasing total flower cover increased total grasshopper species richness (Table 2, Fig. 5h). Caelifera were significantly negatively affected by higher amounts of forest cover in the surrounding landscape (Table 2). We found Stenobothrus lineatus to be significantly associated with managed meadows.

Grasshopper species assemblages did not differ between meadow types (PERMANOVA, main-test: $\mathrm{p}=0.257$ ). 94.01\% of the similarity of 61.63 in managed meadows was due to the species Chorthippus biguttulus, Stenobothrus lineatus, Pseudochorthippus parallelus, Metrioptera brachyptera, Roeseliana roeselii and Euthystira brachyptera. $84 \%$ of the similarity of 53.42 in abandoned meadows was explained by the species Euthystira brachyptera, Pholidoptera griseoaptera, Gomphocerippus rufus, Pseudochorthippus parallelus, Roeseliana roeselii, and Chorthippus biguttulus. The average dissimilarity between meadow types was 52.36, with Stenobothrus lineatus, Metrioptera brachyptera, Pholidoptera griseoaptera, Gomphocerippus rufus, Chorthippus biguttulus, Roeseliana roeselii, Barbitistes serricauda and Pholidoptera aptera explaining $67.13 \%$ of the dissimilarity.

\section{Landscape structure and vegetation parameters}

Managed meadows comprised a significantly higher total plant species richness as well as a higher total flower cover compared to abandoned meadows ( $\mathrm{F}=38.17, \mathrm{p}<0.001$ and $\mathrm{F}=6.06, \mathrm{p}=0.019$, respectively, ANOVA). Similarly, managed meadows harboured a significantly higher number of plant species with hidden nectar flowers $(\mathrm{F}=88.05$, $\mathrm{p}<0.001)$. Vegetation cover as well as number of plant species with open nectar flowers did not differ between habitat types. Surrounding open landscape and surrounding forest cover were significantly negatively correlated $\left(\mathrm{R}^{2}=-0.96 ; \mathrm{p}<0.001\right)$. Flower cover significantly increased with increasing numbers of plant species $\left(\mathrm{R}^{2}=0.44 ; \mathrm{p}=0.012\right)$. Number of plant species were significantly positively correlated with number of plants with hidden nectar flowers $\left(\mathrm{R}^{2}=0.74 ; \mathrm{p}<0.001\right)$ and number of plants with open nectar flowers $\left(\mathrm{R}^{2}=0.37 ; \mathrm{p}=0.037\right)$. Numbers of hidden nectar plants marginally significantly increased with increasing flower cover $\left(\mathrm{R}^{2}=0.34 ; \mathrm{p}=0.057\right)$. A list of the recorded plant species, the mean values for vegetation and flower cover and mean numbers of plant species providing open and hidden nectar flowers are given in Appendix D.

\section{Discussion}

Our results showed a positive effect of extensive management on total bumblebee species richness, particularly on long-tongued bumblebee species. This positive effect is mainly attributable to the higher total flower cover and the higher number of plant species which provided hidden nectar flowers in the investigated annually mown meadows. As a consequence of abandonment, it is likely that plant species richness decreased (e.g. Stampfli and Zeiter, 1999; Pykälä et al., 2005), which subsequently led to a reduction of floral resources (Maurer et al., 2005). In our study, there was also a positive association between total flower cover and plant species richness. This illustrates the importance of maintaining extensively managed, species-rich meadows to preserve local bumblebee richness. In addition, these meadows provide an adequate supply of suitable foraging resources throughout almost the entire activity period of bumblebees, except for the time between mowing and the emergence of new flowers. The importance of providing flower-rich habitats for bumblebees has already been 
stressed by numerous authors (e.g. Dramstad and Fry, 1995; Carvell et al., 2006; Ahrné et al., 2009). Similar species assemblages between meadow types suggests the provision of a sufficient amount of suitable foraging plants in abandoned meadows (Walcher et al., 2017). Further, bumblebees are highly mobile organisms which use a wide range of habitat types (e.g. Darvill et al., 2004; Westphal et al., 2006; Carvell et al., 2017), and both meadow types lay within their flight range.

Managed meadows contained significantly higher numbers of phytophagous bug species compared to abandoned meadows. Effects of management on several bug species were also shown in other studies (e.g. Di Giulio et al., 2001). Due to a reduced plant species richness in abandoned meadows we assume that suitable host plants for phytophagous bug species might be lost during the process of secondary succession (Tasser and Tappeiner, 2002). The managed meadows provided a range of suitable host plants for many bug species, as many of them were polyphagous species using a range of different plant species and families (e.g. Di Giulio and Edwards, 2003; Wachmann et al., 2004, 2007, 2008). True bugs were positively related with surrounding open landscape, revealing the importance of this landscape factor for the observed bugs (Torma et al., 2017). Most of the examined bug species in the present study are associated with open grassland habitats (e.g. Wachmann et al., 2004, 2007, 2008). This might explain the positive relationship with surrounding open landscape, because these species can utilize the supplementary resources in the surrounding meadows depending on their food specialization (Torma et al., 2017). In addition, these habitats can also be regarded as suitable refuges during mowing of the extensively managed meadows or as supplementary overwintering habitats. Most of the detected species were found in both habitat types. True bugs are usually very mobile organisms with a high dispersal potential (Bröring and Wiegleb, 2005; Yanhui et al., 2007; Reynolds et al., 2013). In addition, many of the bug species found in both managed and abandoned meadows were generalist species which do not depend on a specific habitat (e.g. Di Giulio et al., 2001; Wachmann et al., 2004, 2007, 2008). This and the ability to migrate over long distances might explain the lack of differences in species assemblages between both habitat types. The positive relationship between bug species and total flower cover confirms the results of some other studies (Frank and Kuenzle, 2006; Zurbrügg and Frank, 2006). Around $70 \%$ of the collected bugs are reported to feed or stay mainly on inflorescences (Wachmann et al., 2004, 2007, 2008). This explains the positive relationship between bugs and flower cover in the present study. In general, both managed and abandoned meadows are beneficial for various bug species, while abandoned meadows, which are not yet regrown with woody plants, are still a valuable habitat for many bug species inhabiting open landscapes.

Several studies on grassland habitats revealed a negative influence of land-use abandonment on grasshoppers, in which abandonment led to a decline in grasshopper species richness (Marini et al., 2009; Uchida and Ushimaru, 2014; Uchida et al., 2016). Our results, on the other hand, supports the findings of other studies (Bonari et al., 2017; Walcher et al., 2017), in that grasshoppers did not show any response to land-use abandonment. Most of our observed grasshopper species are considered to be habitat generalists. Therefore, we assume that they are well adapted to the habitat conditions of both managed and abandoned meadows. Interestingly, there was a positive relationship between total grasshopper species richness and flower cover. We interpret this as an indirect effect of management, as there is no evidence in literature of grasshoppers using inflorescences as a direct food source. Zahn et al. (2010) showed a positive correlation 
between grasshopper abundance and total flower cover. More likely, the factor flower cover is an indicator of habitat conditions and vegetation development in the two management types. Managed meadows are particularly important habitats for some of the observed grasshopper species. For example, Stenobothrus lineatus was found to be a characteristic species of the managed meadows. This species requires regularly mown meadows with a low sward height and some places of bare ground (Behrens and Fartmann, 2004). However, abandoned meadows were characterized by taller vegetation and the presence of certain bushes and small trees. In general, Ensifera prefer more structured habitat types containing trees and shrubs (Baur et al., 2006b; Marini et al., 2009) and some of the Ensifera species were exclusively or almost exclusively detected in abandoned meadows. A species which showed a particular preference for abandoned meadows was Tettigonia cantans. This species requires well-structured habitat types with dense vegetation (Baur et al., 2006b). The negative relationship between Caelifera and surrounding forest cover is due to the fact that none of the observed Caelifera species would choose closed forest as habitat type, since they are known to have an affinity for open habitats. There was no difference between species assemblages in managed and abandoned meadows. This result is in contrast to other studies (e.g. Fartmann et al., 2012; Walcher et al., 2017) who found that species assemblages differed between successional stages of grasslands. Most of the grasshopper species we observed have no special preference for a specific habitat type (Baur et al., 2006b) but are more sensitive to vegetation characteristics (Gardiner et al., 2002). It can be assumed that most of the observed grasshopper species found suitable microhabitats in both meadow types, and thus contain similar species assemblages.

\section{Conclusion}

Extensive management of meadows turned out to be an important management scheme to sustain bumblebee and true bug richness in the nature reserve Eisenwurzen region. High plant richness in the extensively mown meadows was associated with high flower cover, which contributed to high richness and abundance of the three insect groups studied. Both types of meadows harboured a similar composition of the three insect taxa. This shows that abandoned meadows, as long as they are not yet re-grown into forest, can act as suitable habitat for many of the observed species. However, a conversion into closed forest would deteriorate habitat conditions which are suitable for most species inhabiting open habitats. Thus, a regular removal of shrubs and trees is required for the maintenance of this meadow type.

Acknowledgements. We want to thank the land owners and farmers for their permission to investigate insects and plants on their meadows. Thanks to the Austrian Academy of Sciences (project: Healthy Alps) for supporting this study.

\section{REFERENCES}

[1] Ahrné, K., Bengtsson, J., Elmqvist, T. (2009): Bumble bees (Bombus spp) along a gradient of increasing urbanization. - PLoS ONE 4: e5574.

[2] Bates, D., Maechler, M., Bolker, B., Walker, S. (2015): Fitting linear mixed-effects models using lme4. - Journal of Statistical Software 67: 1-48. 
[3] Baur, B., Cremene, C., Groza, G., Rakosy, L., Schileyko, A. A., Baur, A., Stoll, P., Erhardt, A. (2006a): Effects of abandonment of subalpine hay meadows on plant and invertebrate diversity in Transylvania, Romania. - Biological Conservation 132: 261-273.

[4] Baur, B., Baur, H., Roesti, C., Roesti, D. (eds.) (2006b): Die Heuschrecken der Schweiz. - Haupt, Bern, Switzerland.

[5] Behrens, M., Fartmann, T. (2004): Habitatpräferenzen und Phänologie der Heidegrashüpfer Stenobothrus lineatus, Stenobothrus nigromaculatus und Stenobothrus stigmaticus in der Medebacher Bucht (Südwestfalen/Nordhessen). - Articulata 19: 141165 .

[6] Bonari, G., Fajmon, K., Malenovský, I., Zelený, D., Holuša, J., Jongepierová, I., Kočárek, P., Ondřej, K., Uřičáŕ, J., Chytrý, M. (2017): Management of semi-natural grasslands benefiting both plant and insect diversity: The importance of heterogeneity and tradition. - Agriculture Ecosystems and Environment 246: 243-252.

[7] Bröring, U., Wiegleb, G. (2005): Soil zoology: Colonization, distribution, and abundance of terrestrial Heteroptera in open landscapes of former brown coal mining areas. Ecological Engineering 24: 135-147.

[8] Carvell, C. (2002): Habitat use and conservation of bumblebees (Bombus spp.) under different grassland management regimes. - Biological Conservation 103: 33-49.

[9] Carvell, C., Roy, D. B., Smart, S. M., Pywell, R. F., Preston, C. D., Goulson, D. (2006): Declines in forage availability for bumblebees at a national scale. - Biological Conservation 132: 481-489.

[10] Carvell, C., Bourke, A. F. G., Dreier, S., Freeman, S. N., Hulmes, S., Jordan, W. C., Redhead, J. W., Sumner, S., Wang, J., Heard, M. S. (2017): Bumblebee family lineage survival is enhanced in high-quality landscapes. - Nature 543: 547-549.

[11] Chytrý, M., Dražil, T., Hájek, M., Kalníková, V., Preislerová, Z., Šibík, J., Ujházy, K., Axmanová, I., Bernátová, D., Blanár, D., Dančák, M., Dřevojan, P., Fajmon, K., Galvánek, D., Hájková, P., Herben, T., Hrivnák, R., Janeček, Š., Janišová, M., Jiráská, Š., Kliment, J., Kochjarová, J., Lepš, J., Leskovjanská, A., Merunková, K., Mládek, J., Slezák, M., Šeffer, J., Šefferová, V., Škodová, I., Uhlířová, J., Ujházyová, M., Vymazalová, M. (2015): The most species-rich plant communities in the Czech Republic and Slovakia (with new world records). - Preslia 87: 217-278.

[12] Crawley, M. J. (ed.) (2013): The R Book. - Wiley, New York.

[13] Darvill, B., Knight, M. E., Goulson, D. (2004): Use of genetic markers to quantify bumblebee foraging range and nest density. - Oikos 107: 471-478.

[14] De Cáceres, M., Jansen, F. (2015): Indicspecies: Relationship between species and group of sites. - R Package version 1.7.5.

[15] Dengler, J., Bergmeier, E., Willner, W., Chytrý, M. (2013): Towards a consistent classification of European grasslands. - Applied Vegetation Science 16: 518-520.

[16] Di Giulio, M., Edwards, P. J., Meister, E. (2001): Enhancing insect diversity in agricultural grasslands: the roles of management and landscape structure. - Journal of Applied Ecology 38: 310-319.

[17] Di Giulio, M., Edwards, P. J. (2003): The influence of host plant diversity and food quality on larval survival of plant feeding heteropteran bugs. - Ecological Entomology 28: 51-57.

[18] Dramstad, W., Fry, G. (1995): Foraging activity of bumblebees (Bombus) in relation to flower resources on arable land. - Agriculture Ecosystem Environment 53: 123-135.

[19] Duelli, P., Obrist, M. K. (2003): Biodiversity indicators: the choice of values and measures. - Agriculture Ecosystem Environment 98: 87-98.

[20] Fartmann, T., Krämer, B., Stelzner, F., Poniatowski, D. (2012): Orthoptera as ecological indicators for succession in steppe grassland. - Ecological Indicators 20: 337-344.

[21] Fischer, M., Rudmann-Maurer, K., Weyand, A., Stöcklin, J. (2008): Agricultural land use and biodiversity in the Alps: how cultural tradition and socioeconomically motivated 
changes are shaping grassland biodiversity in the Swiss Alps. - Mountain Research and Development 28: 148-155.

[22] Frank, T., Künzle, I. (2006): Effect of early succession in wildflower areas on bug assemblages (Insecta: Heteroptera). - European Journal of Entomology 103: 61-70.

[23] Gardiner, T., Pye, M., Field, R., Hill, J. (2002): The influence of sward height and vegetation composition in determining the habitat preferences of three Chorthippus species (Orthoptera: Acrididae) in Chelmsford, Essex, UK. - Journal of Orthoptera Research 11: 207-213.

[24] Gellrich, M., Baur, P., Koch, B., Zimmermann, N. E. (2007): Agricultural land abandonment and natural forest re-growth in the Swiss mountains: a spatially explicit economic analysis. - Agriculture Ecosystems and Environment 118: 93-108.

[25] Gokcezade, J. F., Gereben-Krenn, B-A., Neumayer, J., Krenn, H. W. (2015): Feldbestimmungsschlüssel für die Hummeln Österreichs, Deutschlands und der Schweiz (Hymenoptera, Apidae). - Linzer Biologische Beiträge 47: 5-42.

[26] Goulson, D., Hanley, M. E., Darvill, B., Ellis, J. S., Knight, M. E. (2005): Causes of rarity in bumblebees. - Biological Conservation 122: 1-8.

[27] Goulson, D., Nicholls, E., Botias, C., Rotheray, E. L. (2015): Bee declines driven by combined stress from parasites, pesticides, and lack of flowers. - Science 347: 14351444.

[28] Graf, R., Müller, M., Korner, P., Jenny, M., Jenni, L. (2014): 20\% loss of unimproved farmland in 22 years in the Engadin, Swiss Alps. - Agriculture Ecosystems and Environment 185: 48-58.

[29] Haberl, H. (2009): Towards an integrated model of socioeconomic biodiversity drivers, pressures and impacts. A feasibility study based on three European long-term socioecological research platforms. - Ecological Economics 68: 1797-1812.

[30] Hansson, M., Fogelfors, H. (2000): Management of a semi-natural grassland; results from a 15-year-old experiment in southern Sweden. - Journal of Vegetation Science 11: 31-38.

[31] Harrison, X. A. (2014): Using observation-level random effects to model overdispersion in count data in ecology and evolution. - PeerJ 2: e616.

[32] Hejcman, M., Hejcmanová, V., Pavlů, V., Beneš, J. (2013): Origin and history of grasslands in Central Europe - a review. - Grass and Forage Science 68: 345-363.

[33] Hilbe, J., Robinson, A. (2014): msme: Functions and Datasets for "Methods of Statistical Model Estimation". - R Package version 0.5.1.

[34] Kleiber, C., Zeileis, A., Zeileis, M. A. (2015): AER: Applied econometrics with R. - R Package version 1.2-4.

[35] Komac, B., Kéfi, S., Nuche, P., Escós, J., Alados, C. L. (2013): Modeling shrub encroachment in subalpine grasslands under different environmental and management scenarios. - Journal of Environmental Management 121: 160-169.

[36] Kosior, A., Celary, W., Olejniczak, P., Fijał, J. (2007): The decline of the bumblebees and cuckoo bees (Hymenoptera: Apidae: Bombini) of Western and Central Europe. - Oryx 41: 79-88.

[37] Lessard-Therrien, M., Humbert, J-Y., Hajdamowicz, I., Stańska, M., van Klink, R., Lischer, L., Arlettaz, R. (2018): Impacts of management intensification on grounddwelling beetles and spiders in semi-natural mountain grasslands. - Agriculture Ecosystems and Environment 251: 59-66.

[38] Marini, L., Fontana, P., Battisti, A., Gaston, K. J. (2009): Response of orthopteran diversity to abandonment of semi-natural meadows. - Agriculture Ecosystems and Environment 132: 232-236.

[39] Maurer, K., Weyand, A., Fischer, M., Stöcklin, J. (2006): Old cultural traditions, in addition to land use and topography, are shaping plant diversity of grasslands in the Alps. - Biological Conservation 130: 438-446.

[40] Meyer, S., Unternährer, D., Arlettaz, R., Humbert, J-Y., Menz, M. H. M. (2017): Promoting diverse communities of wild bees and hoverflies requires a landscape 
approach to managing meadows. - Agriculture Ecosystems and Environment 239: 376384.

[41] Niedrist, G., Tasser, E., Lüth, C., Dalla Via, J., Tappeiner, U. (2009): Plant diversity declines with recent land use changes in European Alps. - Plant Ecology 202: 195-210.

[42] Nieto, A., Ralph, G. M., Comeros-Raynal, M. T., Kemp, J., García Criado, M., Allen, D. J., Dulvy, N. K., Walls, R. H. L., Russell, B., Pollard, D., García, S., Craig, M., Collette, B. B., Pollom, R., Biscoito, M., Labbish Chao, N., Abella, A., Afonso, P., Álvarez, H., Carpenter, K. E., Clò, S., Cook, R., Costa, M. J., Delgado, J., Dureuil, M., Ellis, J. R., Farrell, E. D., Fernandes, P., Florin, A-B., Fordham, S., Fowler, S., Gil de Sola, L., Gil Herrera, J., Goodpaster, A., Harvey, M., Heessen, H., Herler, J., Jung, A., Karmovskaya, E., Keskin, C., Knudsen, S. W., Kobyliansky, S., Kovačić, M., Lawson, J. M., Lorance, P., McCully Phillips, S., Munroe, T., Nedreaas, K., Nielsen, J., Papaconstantinou, C., Polidoro, B., Pollock, C. M., Rijnsdorp, A. D., Sayer, C., Scott, J., Serena, F., SmithVaniz, W. F., Soldo, A., Stump, E., Williams, J. T. (2014): European Red List of bees. Publication Office of the European Union, Luxembourg.

[43] Poschlod, P., Baumann, A., Karlik, P. (2009): Origin and development of grasslands in Central Europe. - In: Veen, P., Jefferson, R., de Schmidt, J., Van der Straaten, J. (eds.) Grasslands in Europe of high nature value. KNNV Publishing, Zeist.

[44] Pötsch, E. M., Blaschka, A., Resch, R. (2015): Impact of different management systems and location parameters on floristic diversity of mountainous grassland. - Grassland Science in Europe 10: 315-318.

[45] Prévosto, B., Kuiters, L., Bernhardt-Römermann, M., Dölle, M., Schmidt, W., Hoffmann, M., Van Uytvanck, J., Bohner, A., Kreiner, D., Stadler, J., Klotz, S., Brandl, R. (2011): Impacts of land abandonment on vegetation: successional pathways in European habitats. - Folia Geobotanica 46: 303-325.

[46] Price, B., Kienast, F., Seidl, F., Ginzler, C., Verburg, P. H., Bolliger, J. (2015): Future landscapes of Switzerland: Risk areas for urbanisation and land abandonment. - Applied Geography 57: 32-41.

[47] Pykälä, J., Luoto, M., Heikkinen, R. K., Kontula, T. (2005): Plant species richness and persistence of rare plants in abandoned semi-natural grasslands in northern Europe. Basic and Applied Ecology 6(1): 25-33.

[48] R Core Team (2015): R: A language and environment for statistical computing. - R Foundation for Statistical Computing, Vienna, Austria. https://www.R-project.org/.

[49] Rey Benayas, J. M., Martins, A., Nicolau, J. M., Schulz, J. (2007): Abandonment of agricultural land: an overview of drivers and consequences. - CAB Reviews 2: 1-14.

[50] Reynolds, D. R., Nau, B. S., Chapman, J. W. (2013): High altitude migration of Heteroptera in Britain. - European Journal of Entomology 110: 483-492.

[51] Roesti, C., Keist, B. (2009): Die Stimmen der Heuschrecken. - Haupt, Bern, Switzerland.

[52] Schwab, A., Dubois, D., Fried, P. M., Edwards, P. J. (2002): Estimating the biodiversity of hay meadows in north-eastern Switzerland on the basis of vegetation structure. Agriculture Ecosystems and Environment 93: 197-209.

[53] Stampfli, A., Zeiter, M. (1999): Plant species decline due to abandonment of meadows cannot easily be reversed by mowing. A case study from the southern Alps. - Journal of Vegetation Science 10: 151-164.

[54] Strauss, G. (2010): CORISA Wanzenabbildungen. Biberach. - www.corisa.de.

[55] Strijker, D. (2005): Marginal lands in Europe-causes of decline. - Basic and Applied Ecology 6: 99-106.

[56] Suttie, J. M., Reynolds, S. G., Batello, C. (2005): Grasslands of the world. - Plant Production and Protection Series 34, Food and Agriculture Organization of the United Nations, Rome.

[57] Tasser, E., Tappeiner, U. (2002): Impact of land use changes on mountain vegetation. Applied Vegetation Science 5: 173-184. 
[58] Tasser, E., Walde, J., Tappeiner, U., Teutsch, A., Noggler, W. (2007): Land-use changes and natural reforestation in the Eastern Central Alps. - Agric. Ecosyst. Environ. 118: 115129.

[59] Torma, A., Bozsó, M., Tölgyesi, C., Gallé, R. (2017): Relationship of different feeding groups of true bugs (Hemiptera: Heteroptera) with habitat and landscape features in Pannonic salt grassland. - Journal of Insect Conservation 21: 645-656.

[60] Uchida, K., Ushimaru, A. (2014): Biodiversity declines due to abandonment and intensification of agricultural lands: patterns and mechanisms. - Ecological Monographs 84: 637-658.

[61] Uchida, K., Takahashi, S., Shinohara, T., Ushimaru, A. (2016): Threatened herbivorous insects maintained by long-term traditional management practices in semi-natural grasslands. - Agriculture Ecosystems and Environment 221: 156-162.

[62] Van Noordwijk, C. G. E., Baeten, L., Turin, H., Heijerman, T., Alders, K., Boer, P., Mabelis, A. A., Aukema, B., Noordam, A., Remke, E., Siepeö, H., Berg, M. P., Bonte, D. (2017): 17 years of grassland management leads to parallel local and regional biodiversity shifts among a wide range of taxonomic groups. - Biodiversity and Conservation 26: 717-734.

[63] Wachmann, E., Melber, A., Deckert, J. (2004): Die Tierwelt Deutschlands. Wanzen Band 2 Cimicomorpha. - Goecke \& Evers, Keltern.

[64] Wachmann, E., Melber, A., Deckert, J. (2007): Die Tierwelt Deutschlands. Wanzen Band 3 Pentatomorpha I. - Goecke \& Evers, Keltern.

[65] Wachmann, E., Melber, A., Deckert, J. (2008): Die Tierwelt Deutschlands. Wanzen Band 4 Pentatomorpha II. - Goecke \& Evers, Keltern.

[66] Wagner, E. (1952): Blindwanzen und Miriden. Die Tierwelt Deutschlands und der angrenzenden Meeresteile. - Fischer, Jena.

[67] Wagner, E. (1966): Die Tierwelt Deutschlands und der angrenzenden Meeresteile nach ihren Merkmalen und nach ihrer Lebensweise, Wanzen oder Heteroptera I, Pentatomorpha. - Fischer, Jena.

[68] Wagner, E. (1967): Die Tierwelt Deutschlands und der angrenzenden Meeresteile nach ihren Merkmalen und nach ihrer Lebensweise, Wanzen oder Heteroptera II, Cimicomorpha. - Fischer, Jena.

[69] Walcher, R., Karrer, J., Sachslehner, L., Bohner, A., Pachinger, B., Brandl, D., Zaller, J. G., Arnberger, A., Frank, T. (2017): Diversity of bumblebees, heteropteran bugs and grasshoppers maintained by both: abandonment and extensive management of mountain meadows in three regions across the Austrian and Swiss Alps. - Landscape Ecology 32: 1937-1951.

[70] Wesche, K., Krause, B., Culmsee, H., Leuschner, C. (2012): Fifty years of change in Central European grassland vegetation: Large losses in species richness and animalpollinated plants. - Biological Conservation 150: 76-85.

[71] Westphal, C., Steffan-Dewenter, I., Tscharntke, T. (2006): Bumblebees experience landscapes at different spatial scales: possible implications for coexistence. - Oecologia 149: 289-300.

[72] Yanhui, L., Wu, K., Guo, Y. (2007): Flight potential of Lygus lucorum (Meyer-Dür) (Heteroptera: Miridae). - Environmental Entomology 36: 1007-1013.

[73] Zahn, A., Englmaier, I., Drobny, M. (2010): Food availability for insectivores in grasslands - arthropod abundance in pastures, meadows and fallow land. - Applied Ecology and Environmental Research 8: 87-100.

[74] Zurbrügg, C., Frank, T. (2006): Factors influencing bug diversity (Insecta: Heteroptera) in semi-natural habitats. - Biodiversity and Conservation 15: 275-294. 


\section{APPENDICES}

Species lists of bumblebees, heteropteran bugs, grasshoppers and plants (with related vegetation parameters) in the study region Eisenwurzen.

Appendix A. Number of individuals of bumblebees in managed and abandoned meadows in the Eisenwurzen region in 2015 and 2016 (M1-M4...managed meadows, A1-A4...abandoned meadows)

\begin{tabular}{|c|c|c|c|c|c|c|c|c|}
\hline \multirow[b]{3}{*}{ Bumblebee species } & $\begin{array}{c}\text { Eisenwurzen } \\
\text { Managed }\end{array}$ & \multicolumn{7}{|c|}{ Abandoned } \\
\hline & M1 & M2 & M3 & M4 & A1 & $\mathrm{A} 2$ & A3 & $\mathrm{A} 4$ \\
\hline & & & & & & & & \\
\hline Bombus hortorum & 5 & 6 & 0 & 3 & 0 & 1 & 0 & 1 \\
\hline Bombus humilis & 2 & 1 & 2 & 1 & 0 & 0 & 15 & 2 \\
\hline Bombus hypnorum & 0 & 0 & 0 & 1 & 0 & 0 & 0 & 2 \\
\hline Bombus lapidarius & 4 & 2 & 2 & 0 & 0 & 0 & 3 & 0 \\
\hline Bombus lucorum & 3 & 1 & 0 & 8 & 0 & 0 & 0 & 0 \\
\hline Bombus mucidus & 0 & 0 & 3 & 0 & 0 & 0 & 0 & 0 \\
\hline Bombus pascuorum & 3 & 3 & 0 & 0 & 0 & 1 & 3 & 0 \\
\hline Bombus pratorum & 0 & 0 & 2 & 0 & 1 & 0 & 0 & 0 \\
\hline Bombus terrestris & 3 & 3 & 0 & 0 & 1 & 0 & 2 & 0 \\
\hline Bombus wurflenii & 1 & 0 & 1 & 0 & 0 & 0 & 0 & 0 \\
\hline Psithyrus barbutellus & 0 & 0 & 0 & 0 & 0 & 0 & 1 & 1 \\
\hline Psithyrus bohemicus & 0 & 1 & 0 & 2 & 0 & 0 & 0 & 0 \\
\hline Psithyrus campestris & 0 & 0 & 1 & 0 & 0 & 0 & 0 & 0 \\
\hline
\end{tabular}

Appendix B. Number of individuals of heteropteran bugs in managed and abandoned meadows in the Eisenwurzen region in 2015 and 2016 (M1-M4...managed meadows, A1A4...abandoned meadows)

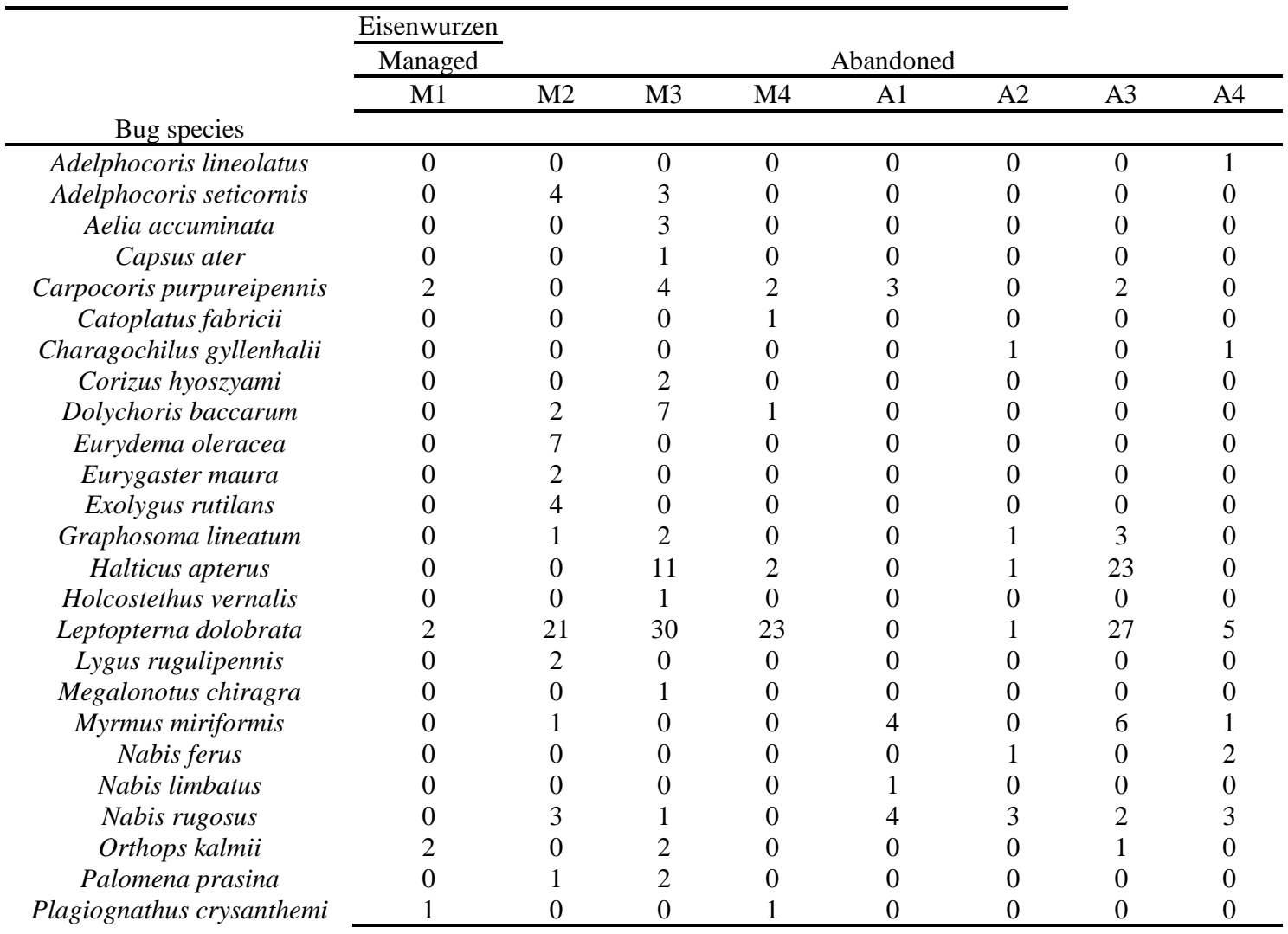




\begin{tabular}{|c|c|c|c|c|c|c|c|c|}
\hline \multirow[b]{3}{*}{ Bug species } & \multirow{2}{*}{$\begin{array}{c}\text { Managed } \\
\text { M1 }\end{array}$} & \multicolumn{7}{|c|}{ Abandoned } \\
\hline & & M2 & M3 & M4 & $\mathrm{A} 1$ & $\mathrm{~A} 2$ & $\mathrm{~A} 3$ & A4 \\
\hline & & & & & & & & \\
\hline Polymerus microphtalmus & 0 & 0 & 0 & 1 & 0 & 1 & 2 & 7 \\
\hline Polymerus unifasciatus & 0 & 3 & 0 & 0 & 0 & 0 & 0 & 0 \\
\hline Rhopalus subrufus & 1 & 0 & 0 & 0 & 0 & 0 & 0 & 0 \\
\hline Rubiconia intermedia & 1 & 0 & 0 & 0 & 0 & 0 & 0 & 0 \\
\hline Stenodema calcarata & 0 & 0 & 0 & 0 & 8 & 1 & 0 & 0 \\
\hline Stictopleurus crassicornis & 0 & 0 & 3 & 0 & 0 & 0 & 0 & 0 \\
\hline Stictopleurus punctatonervosus & 0 & 0 & 1 & 0 & 0 & 0 & 0 & 0 \\
\hline
\end{tabular}

Appendix C. Presencelabsence of grasshopper species in managed and abandoned meadows in the Eisenwurzen region in 2015 and 2016 (M1-M4...managed meadows, A1A4...abandoned meadows)

\begin{tabular}{ccccccc}
\hline & \multicolumn{1}{l}{ Eisenwurzen } & & & & \\
& \multicolumn{2}{c}{ Managed } & & & Abandoned & \\
\cline { 2 - 6 } & M1 & M2 & M3 & A1 & A2 & A3 \\
\cline { 2 - 6 } Grasshopper species & & & & & & \\
\hline Barbitistes serricauda & 0 & 1 & 0 & 1 & 1 & 1 \\
Chorthippus biguttulus & 1 & 1 & 1 & 1 & 0 & 1 \\
Chorthippus dorsatus & 0 & 0 & 1 & 0 & 0 & 0 \\
Chrsyochraon dispar & 0 & 1 & 0 & 0 & 0 & 1 \\
Decticus verrucivorus & 1 & 0 & 1 & 0 & 1 & 0 \\
Euthystira brachyptera & 1 & 1 & 0 & 1 & 1 & 1 \\
Gomphocerippus rufus & 0 & 0 & 0 & 1 & 1 & 0 \\
Metrioptera brachyptera & 1 & 0 & 1 & 1 & 0 & 0 \\
Omocestus sp. & 0 & 0 & 0 & 1 & 0 & 0 \\
Pholidoptera aptera & 1 & 0 & 0 & 1 & 1 & 1 \\
Pholidoptera griseoaptera & 1 & 1 & 1 & 1 & 1 & 1 \\
Pseudochorthippus parallelus & 1 & 1 & 1 & 0 & 1 & 1 \\
Roeseliana roeselii & 1 & 1 & 1 & 0 & 1 & 1 \\
Stenobothrus lineatus & 1 & 1 & 1 & 0 & 0 & 0 \\
Tettigonia cantans & 0 & 0 & 0 & 1 & 1 & 1 \\
\hline
\end{tabular}

Appendix D. Presencelabsence of plant species and the means of vegetation cover (in \%) and flower cover (in \%) and mean numbers of plants with open nectar flowers and plants with hidden nectar flowers in managed and abandoned meadows in the Eisenwurzen region in 2015 and 2016 (M1-M4...managed meadows, A1-A4 ...abandoned meadows)

\begin{tabular}{|c|c|c|c|c|c|c|c|c|}
\hline & $\begin{array}{c}\text { Eisenwurzen } \\
\text { Managed }\end{array}$ & & & & Abandoned & & & \\
\hline & M1 & M2 & M3 & M4 & A1 & A2 & A3 & A4 \\
\hline \multicolumn{9}{|l|}{ Vegetation parameters } \\
\hline Vegetation cover (in \%) & 84.925 & 78.93 & 71.75 & 77.77 & 75.915 & 85 & 80.475 & 74.175 \\
\hline Flower cover (in \%) & 2.53 & 5.53 & 1.8725 & 2.2175 & 0.74875 & 0.74875 & 0.75 & 0.875 \\
\hline Plants with open nectar flowers & 5 & 6.5 & 3 & 6 & 5 & 5.5 & 3 & 4 \\
\hline \multirow[t]{3}{*}{ Plants with hidden nectar flowers } & 11.5 & 8.5 & 7.5 & 7.5 & 3 & 5 & 2 & 3.5 \\
\hline & Managed & & & & Abandoned & & & \\
\hline & M1 & M2 & M3 & M4 & $\mathrm{A} 1$ & $\mathrm{~A} 2$ & A3 & A4 \\
\hline \multicolumn{9}{|l|}{ Plant species } \\
\hline Acer pseudoplatanus & 1 & 0 & 0 & 0 & 0 & 0 & 0 & 0 \\
\hline Achillea millefolium agg. & 1 & 1 & 1 & 1 & 0 & 1 & 1 & 1 \\
\hline Acinos alpinus & 1 & 0 & 0 & 0 & 0 & 0 & 0 & 0 \\
\hline Aegopodium podagraria & 0 & 1 & 0 & 1 & 0 & 1 & 1 & 1 \\
\hline Agrostis capillaris & 1 & 1 & 0 & 1 & 0 & 1 & 1 & 1 \\
\hline Ajuga genevensis & 0 & 0 & 1 & 0 & 0 & 0 & 0 & 0 \\
\hline
\end{tabular}




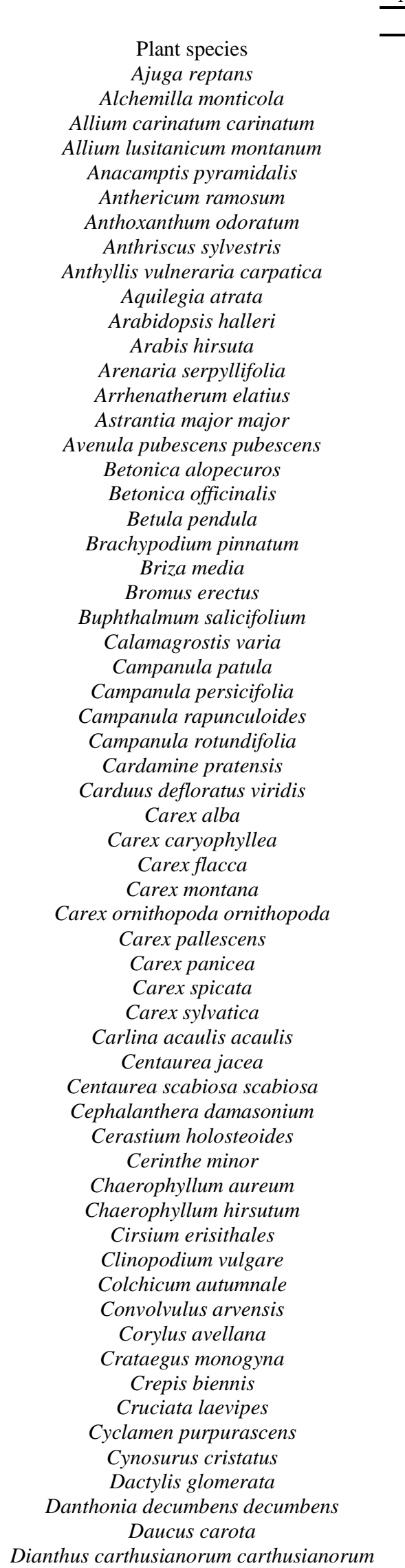

Plant species Ajuga reptans

ramosum

Abidopsis haller

Arenaria serpyllifolia

Arrhenatherum elatius

Betonica alopecuros

Benica officinalis

hypodium pinnatu

Briza media

Bhthalmum salicifolium

Calamagrostis varia

Campanula patula

\begin{tabular}{|c|c|c|c|c|}
\hline Managed & & & & ando \\
\hline M1 & M2 & M3 & M4 & $\overline{\mathrm{A} 1}$ \\
\hline
\end{tabular}

0

0

1

0

1

0

0

0

1

0

0

0

1

0

0$$
1
$$

\begin{tabular}{|c|c|}
\hline \multicolumn{2}{|c|}{ Ianaged } \\
\hline M1 & M2 \\
\hline 0 & 1 \\
\hline 0 & 1 \\
\hline 1 & 0 \\
\hline 0 & 0 \\
\hline 1 & 0 \\
\hline 0 & 0 \\
\hline 0 & 1 \\
\hline 0 & 1 \\
\hline 1 & 1 \\
\hline 1 & 0 \\
\hline 0 & 1 \\
\hline 0 & 1 \\
\hline 0 & 0 \\
\hline 0 & 1 \\
\hline 1 & 1 \\
\hline 1 & 1 \\
\hline 1 & 0 \\
\hline 0 & 1 \\
\hline 1 & 0 \\
\hline 1 & 1 \\
\hline 1 & 1 \\
\hline 1 & 1 \\
\hline 1 & 1 \\
\hline 0 & 0 \\
\hline 0 & 1 \\
\hline 0 & 1 \\
\hline 0 & 0 \\
\hline 1 & 1 \\
\hline 0 & 0 \\
\hline 1 & 0 \\
\hline 1 & 0 \\
\hline 1 & 0 \\
\hline 1 & 0 \\
\hline 0 & 1 \\
\hline 1 & 0 \\
\hline 0 & 0 \\
\hline 1 & 0 \\
\hline 0 & 0 \\
\hline 0 & 0 \\
\hline 1 & 0 \\
\hline 1 & 1 \\
\hline
\end{tabular}

\begin{tabular}{|c|c|}
\hline$\frac{\text { anage }}{\text { M1 }}$ & M2 \\
\hline 0 & 1 \\
\hline 0 & 1 \\
\hline 1 & 0 \\
\hline 0 & 0 \\
\hline 1 & 0 \\
\hline 0 & 0 \\
\hline 0 & 1 \\
\hline 0 & 1 \\
\hline 1 & 1 \\
\hline 1 & 0 \\
\hline 0 & 1 \\
\hline 0 & 1 \\
\hline 0 & 0 \\
\hline 0 & 1 \\
\hline 1 & 1 \\
\hline 1 & 1 \\
\hline 1 & 0 \\
\hline 0 & 1 \\
\hline 1 & 0 \\
\hline 1 & 1 \\
\hline 1 & 1 \\
\hline 1 & 1 \\
\hline 1 & 1 \\
\hline 0 & 0 \\
\hline 0 & 1 \\
\hline 0 & 1 \\
\hline 0 & 0 \\
\hline 1 & 1 \\
\hline 0 & 0 \\
\hline 1 & 0 \\
\hline 1 & 0 \\
\hline 1 & 0 \\
\hline 1 & 0 \\
\hline 0 & 1 \\
\hline 1 & 0 \\
\hline 0 & 0 \\
\hline 1 & 0 \\
\hline 0 & 0 \\
\hline 0 & 0 \\
\hline 1 & 0 \\
\hline 1 & 1 \\
\hline
\end{tabular}

\begin{tabular}{|c|c|}
\hline \multicolumn{2}{|l|}{ Aanaged } \\
\hline M1 & M2 \\
\hline 0 & 1 \\
\hline 0 & 1 \\
\hline 1 & 0 \\
\hline 0 & 0 \\
\hline 1 & 0 \\
\hline 0 & 0 \\
\hline 0 & 1 \\
\hline 0 & 1 \\
\hline 1 & 1 \\
\hline 1 & 0 \\
\hline 0 & 1 \\
\hline 0 & 1 \\
\hline 0 & 0 \\
\hline 0 & 1 \\
\hline 1 & 1 \\
\hline 1 & 1 \\
\hline 1 & 0 \\
\hline 0 & 1 \\
\hline 1 & 0 \\
\hline 1 & 1 \\
\hline 1 & 1 \\
\hline 1 & 1 \\
\hline 1 & 1 \\
\hline 0 & 0 \\
\hline 0 & 1 \\
\hline 0 & 1 \\
\hline 0 & 0 \\
\hline 1 & 1 \\
\hline 0 & 0 \\
\hline 1 & 0 \\
\hline 1 & 0 \\
\hline 1 & 0 \\
\hline 1 & 0 \\
\hline 0 & 1 \\
\hline 1 & 0 \\
\hline 0 & 0 \\
\hline 1 & 0 \\
\hline 0 & 0 \\
\hline 0 & 0 \\
\hline 1 & 0 \\
\hline 1 & 1 \\
\hline
\end{tabular}

\begin{tabular}{|c|c|}
\hline \multicolumn{2}{|c|}{ Ianaged } \\
\hline M1 & M2 \\
\hline 0 & 1 \\
\hline 0 & 1 \\
\hline 1 & 0 \\
\hline 0 & 0 \\
\hline 1 & 0 \\
\hline 0 & 0 \\
\hline 0 & 1 \\
\hline 0 & 1 \\
\hline 1 & 1 \\
\hline 1 & 0 \\
\hline 0 & 1 \\
\hline 0 & 1 \\
\hline 0 & 0 \\
\hline 0 & 1 \\
\hline 1 & 1 \\
\hline 1 & 1 \\
\hline 1 & 0 \\
\hline 0 & 1 \\
\hline 1 & 0 \\
\hline 1 & 1 \\
\hline 1 & 1 \\
\hline 1 & 1 \\
\hline 1 & 1 \\
\hline 0 & 0 \\
\hline 0 & 1 \\
\hline 0 & 1 \\
\hline 0 & 0 \\
\hline 1 & 1 \\
\hline 0 & 0 \\
\hline 1 & 0 \\
\hline 1 & 0 \\
\hline 1 & 0 \\
\hline 1 & 0 \\
\hline 0 & 1 \\
\hline 1 & 0 \\
\hline 0 & 0 \\
\hline 1 & 0 \\
\hline 0 & 0 \\
\hline 0 & 0 \\
\hline 1 & 0 \\
\hline 1 & 1 \\
\hline
\end{tabular}

\begin{tabular}{|c|c|}
\hline$\frac{\text { Inage }}{\text { M1 }}$ & M2 \\
\hline 0 & 1 \\
\hline 0 & 1 \\
\hline 1 & 0 \\
\hline 0 & 0 \\
\hline 1 & 0 \\
\hline 0 & 0 \\
\hline 0 & 1 \\
\hline 0 & 1 \\
\hline 1 & 1 \\
\hline 1 & 0 \\
\hline 0 & 1 \\
\hline 0 & 1 \\
\hline 0 & 0 \\
\hline 0 & 1 \\
\hline 1 & 1 \\
\hline 1 & 1 \\
\hline 1 & 0 \\
\hline 0 & 1 \\
\hline 1 & 0 \\
\hline 1 & 1 \\
\hline 1 & 1 \\
\hline 1 & 1 \\
\hline 1 & 1 \\
\hline 0 & 0 \\
\hline 0 & 1 \\
\hline 0 & 1 \\
\hline 0 & 0 \\
\hline 1 & 1 \\
\hline 0 & 0 \\
\hline 1 & 0 \\
\hline 1 & 0 \\
\hline 1 & 0 \\
\hline 1 & 0 \\
\hline 0 & 1 \\
\hline 1 & 0 \\
\hline 0 & 0 \\
\hline 1 & 0 \\
\hline 0 & 0 \\
\hline 0 & 0 \\
\hline 1 & 0 \\
\hline 1 & 1 \\
\hline
\end{tabular}

\begin{tabular}{|c|c|}
\hline M1 & M2 \\
\hline 0 & 1 \\
\hline 0 & 1 \\
\hline 1 & 0 \\
\hline 0 & 0 \\
\hline 1 & 0 \\
\hline 0 & 0 \\
\hline 0 & 1 \\
\hline 0 & 1 \\
\hline 1 & 1 \\
\hline 1 & 0 \\
\hline 0 & 1 \\
\hline 0 & 1 \\
\hline 0 & 0 \\
\hline 0 & 1 \\
\hline 1 & 1 \\
\hline 1 & 1 \\
\hline 1 & 0 \\
\hline 0 & 1 \\
\hline 1 & 0 \\
\hline 1 & 1 \\
\hline 1 & 1 \\
\hline 1 & 1 \\
\hline 1 & 1 \\
\hline 0 & 0 \\
\hline 0 & 1 \\
\hline 0 & 1 \\
\hline 0 & 0 \\
\hline 1 & 1 \\
\hline 0 & 0 \\
\hline 1 & 0 \\
\hline 1 & 0 \\
\hline 1 & 0 \\
\hline 1 & 0 \\
\hline 0 & 1 \\
\hline 1 & 0 \\
\hline 0 & 0 \\
\hline 1 & 0 \\
\hline 0 & 0 \\
\hline 0 & 0 \\
\hline 1 & 0 \\
\hline 1 & 1 \\
\hline
\end{tabular}

\begin{tabular}{|c|c|}
\hline M1 & M2 \\
\hline 0 & 1 \\
\hline 0 & 1 \\
\hline 1 & 0 \\
\hline 0 & 0 \\
\hline 1 & 0 \\
\hline 0 & 0 \\
\hline 0 & 1 \\
\hline 0 & 1 \\
\hline 1 & 1 \\
\hline 1 & 0 \\
\hline 0 & 1 \\
\hline 0 & 1 \\
\hline 0 & 0 \\
\hline 0 & 1 \\
\hline 1 & 1 \\
\hline 1 & 1 \\
\hline 1 & 0 \\
\hline 0 & 1 \\
\hline 1 & 0 \\
\hline 1 & 1 \\
\hline 1 & 1 \\
\hline 1 & 1 \\
\hline 1 & 1 \\
\hline 0 & 0 \\
\hline 0 & 1 \\
\hline 0 & 1 \\
\hline 0 & 0 \\
\hline 1 & 1 \\
\hline 0 & 0 \\
\hline 1 & 0 \\
\hline 1 & 0 \\
\hline 1 & 0 \\
\hline 1 & 0 \\
\hline 0 & 1 \\
\hline 1 & 0 \\
\hline 0 & 0 \\
\hline 1 & 0 \\
\hline 0 & 0 \\
\hline 0 & 0 \\
\hline 1 & 0 \\
\hline 1 & 1 \\
\hline
\end{tabular}

1

\begin{tabular}{|c|c|}
\hline Ianage & \\
\hline M1 & M2 \\
\hline 0 & 1 \\
\hline 0 & 1 \\
\hline 1 & 0 \\
\hline 0 & 0 \\
\hline 1 & 0 \\
\hline 0 & 0 \\
\hline 0 & 1 \\
\hline 0 & 1 \\
\hline 1 & 1 \\
\hline 1 & 0 \\
\hline 0 & 1 \\
\hline 0 & 1 \\
\hline 0 & 0 \\
\hline 0 & 1 \\
\hline 1 & 1 \\
\hline 1 & 1 \\
\hline 1 & 0 \\
\hline 0 & 1 \\
\hline 1 & 0 \\
\hline 1 & 1 \\
\hline 1 & 1 \\
\hline 1 & 1 \\
\hline 1 & 1 \\
\hline 0 & 0 \\
\hline 0 & 1 \\
\hline 0 & 1 \\
\hline 0 & 0 \\
\hline 1 & 1 \\
\hline 0 & 0 \\
\hline 1 & 0 \\
\hline 1 & 0 \\
\hline 1 & 0 \\
\hline 1 & 0 \\
\hline 0 & 1 \\
\hline 1 & 0 \\
\hline 0 & 0 \\
\hline 1 & 0 \\
\hline 0 & 0 \\
\hline 0 & 0 \\
\hline 1 & 0 \\
\hline 1 & 1 \\
\hline
\end{tabular}

1
0

\begin{tabular}{|c|c|}
\hline$\frac{\text { anage }}{\text { M1 }}$ & M2 \\
\hline 0 & 1 \\
\hline 0 & 1 \\
\hline 1 & 0 \\
\hline 0 & 0 \\
\hline 1 & 0 \\
\hline 0 & 0 \\
\hline 0 & 1 \\
\hline 0 & 1 \\
\hline 1 & 1 \\
\hline 1 & 0 \\
\hline 0 & 1 \\
\hline 0 & 1 \\
\hline 0 & 0 \\
\hline 0 & 1 \\
\hline 1 & 1 \\
\hline 1 & 1 \\
\hline 1 & 0 \\
\hline 0 & 1 \\
\hline 1 & 0 \\
\hline 1 & 1 \\
\hline 1 & 1 \\
\hline 1 & 1 \\
\hline 1 & 1 \\
\hline 0 & 0 \\
\hline 0 & 1 \\
\hline 0 & 1 \\
\hline 0 & 0 \\
\hline 1 & 1 \\
\hline 0 & 0 \\
\hline 1 & 0 \\
\hline 1 & 0 \\
\hline 1 & 0 \\
\hline 1 & 0 \\
\hline 0 & 1 \\
\hline 1 & 0 \\
\hline 0 & 0 \\
\hline 1 & 0 \\
\hline 0 & 0 \\
\hline 0 & 0 \\
\hline 1 & 0 \\
\hline 1 & 1 \\
\hline
\end{tabular}

\begin{tabular}{|c|c|}
\hline Ianage & \\
\hline M1 & M2 \\
\hline 0 & 1 \\
\hline 0 & 1 \\
\hline 1 & 0 \\
\hline 0 & 0 \\
\hline 1 & 0 \\
\hline 0 & 0 \\
\hline 0 & 1 \\
\hline 0 & 1 \\
\hline 1 & 1 \\
\hline 1 & 0 \\
\hline 0 & 1 \\
\hline 0 & 1 \\
\hline 0 & 0 \\
\hline 0 & 1 \\
\hline 1 & 1 \\
\hline 1 & 1 \\
\hline 1 & 0 \\
\hline 0 & 1 \\
\hline 1 & 0 \\
\hline 1 & 1 \\
\hline 1 & 1 \\
\hline 1 & 1 \\
\hline 1 & 1 \\
\hline 0 & 0 \\
\hline 0 & 1 \\
\hline 0 & 1 \\
\hline 0 & 0 \\
\hline 1 & 1 \\
\hline 0 & 0 \\
\hline 1 & 0 \\
\hline 1 & 0 \\
\hline 1 & 0 \\
\hline 1 & 0 \\
\hline 0 & 1 \\
\hline 1 & 0 \\
\hline 0 & 0 \\
\hline 1 & 0 \\
\hline 0 & 0 \\
\hline 0 & 0 \\
\hline 1 & 0 \\
\hline 1 & 1 \\
\hline
\end{tabular}

\begin{tabular}{|c|c|}
\hline$\frac{\text { anagee }}{\text { M1 }}$ & $\mathrm{M} 2$ \\
\hline 0 & 1 \\
\hline 0 & 1 \\
\hline 1 & 0 \\
\hline 0 & 0 \\
\hline 1 & 0 \\
\hline 0 & 0 \\
\hline 0 & 1 \\
\hline 0 & 1 \\
\hline 1 & 1 \\
\hline 1 & 0 \\
\hline 0 & 1 \\
\hline 0 & 1 \\
\hline 0 & 0 \\
\hline 0 & 1 \\
\hline 1 & 1 \\
\hline 1 & 1 \\
\hline 1 & 0 \\
\hline 0 & 1 \\
\hline 1 & 0 \\
\hline 1 & 1 \\
\hline 1 & 1 \\
\hline 1 & 1 \\
\hline 1 & 1 \\
\hline 0 & 0 \\
\hline 0 & 1 \\
\hline 0 & 1 \\
\hline 0 & 0 \\
\hline 1 & 1 \\
\hline 0 & 0 \\
\hline 1 & 0 \\
\hline 1 & 0 \\
\hline 1 & 0 \\
\hline 1 & 0 \\
\hline 0 & 1 \\
\hline 1 & 0 \\
\hline 0 & 0 \\
\hline 1 & 0 \\
\hline 0 & 0 \\
\hline 0 & 0 \\
\hline 1 & 0 \\
\hline 1 & 1 \\
\hline
\end{tabular}

\begin{tabular}{|c|c|}
\hline \multicolumn{2}{|c|}{ lanaged } \\
\hline M1 & M2 \\
\hline 0 & 1 \\
\hline 0 & 1 \\
\hline 1 & 0 \\
\hline 0 & 0 \\
\hline 1 & 0 \\
\hline 0 & 0 \\
\hline 0 & 1 \\
\hline 0 & 1 \\
\hline 1 & 1 \\
\hline 1 & 0 \\
\hline 0 & 1 \\
\hline 0 & 1 \\
\hline 0 & 0 \\
\hline 0 & 1 \\
\hline 1 & 1 \\
\hline 1 & 1 \\
\hline 1 & 0 \\
\hline 0 & 1 \\
\hline 1 & 0 \\
\hline 1 & 1 \\
\hline 1 & 1 \\
\hline 1 & 1 \\
\hline 1 & 1 \\
\hline 0 & 0 \\
\hline 0 & 1 \\
\hline 0 & 1 \\
\hline 0 & 0 \\
\hline 1 & 1 \\
\hline 0 & 0 \\
\hline 1 & 0 \\
\hline 1 & 0 \\
\hline 1 & 0 \\
\hline 1 & 0 \\
\hline 0 & 1 \\
\hline 1 & 0 \\
\hline 0 & 0 \\
\hline 1 & 0 \\
\hline 0 & 0 \\
\hline 0 & 0 \\
\hline 1 & 0 \\
\hline 1 & 1 \\
\hline
\end{tabular}

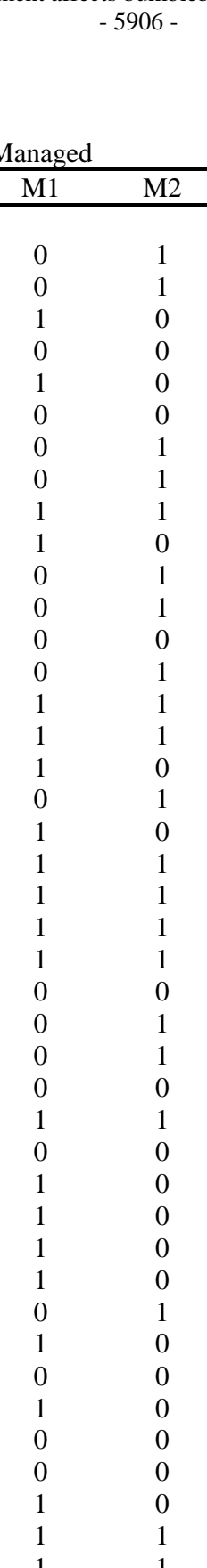

0

0
0
0
0

0
0
0

0
0

0

$\begin{array}{llll}0 & 0 & 0 & 0 \\ 0 & 0 & 0 & 0 \\ 0 & 0 & 0 & 0 \\ 0 & 0 & 1 & 0 \\ 0 & 1 & 0 & 1 \\ 0 & 1 & 0 & 1 \\ 0 & 0 & 0 & 0 \\ 0 & 1 & 0 & 1 \\ 1 & 1 & 0 & 1 \\ 1 & 1 & 0 & 0 \\ 0 & 1 & 0 & 0 \\ 0 & 1 & 1 & 1\end{array}$

$\begin{array}{llll}0 & 0 & 0 & 0 \\ 0 & 0 & 0 & 0 \\ 0 & 0 & 0 & 0 \\ 0 & 0 & 1 & 0 \\ 0 & 1 & 0 & 1 \\ 0 & 1 & 0 & 1 \\ 0 & 0 & 0 & 0 \\ 0 & 1 & 0 & 1 \\ 1 & 1 & 0 & 1 \\ 1 & 1 & 0 & 0 \\ 0 & 1 & 0 & 0 \\ 0 & 1 & 1 & 1\end{array}$




\author{
Plant species \\ Erica carnea \\ Euphorbia amygdaloides \\ Euphorbia cyparissias \\ Euphrasia officinalis rostkoviana \\ Festuca pratensis \\ Festuca rubra rubra \\ Festuca rupicola \\ Fraxinus excelsior \\ Galeopsis tetrahit \\ Galeopsis speciosa \\ Galium album \\ Galium pumilum \\ Galium verum \\ Gentiana verna \\ Gentianella aspera \\ Geranium phaeum phaeum \\ Glechoma hederacea \\ Gymnadenia conopsea conopsea \\ Helianthemum nummularium obscurum \\ Helleborus niger \\ Hieracium pilosella \\ Hieracium spec. \\ Hippocrepis comosa \\ Holcus lanatus \\ Hypericum maculatum \\ Hypericum perforatum \\ Knautia arvensis arvensis \\ Knautia drymeia intermedia \\ Knautia maxima \\ Koeleria pyramidata pyramidata \\ Laserpitium latifolium \\ Lathyrus pratensis \\ Leontodon hispidus hispidus \\ Leucanthemum ircutianum \\ Lilium bulbiferum bulbiferum \\ Linum catharticum \\ Lotus corniculatus \\ Luzula multiflora \\ Medicago falcata \\ Medicago lupulina \\ Melampyrum sylvaticum \\ Mercurialis perennis \\ Molinia caerulea \\ Myosotis arvensis \\ Orchis coriophora \\ Origanum vulgare vulgare \\ Orobanche gracilis \\ Phyteuma orbiculare \\ Pimpinella major major \\ Pimpinella saxifraga saxifraga \\ Plantago lanceolata \\ Plantago media \\ Poa angustifolia \\ Poa trivialis \\ Polygala amarella \\ Polygala chamaebuxus \\ Polygala comosa \\ Polygonatum odoratum \\ Potentilla erecta \\ Potentilla reptans \\ Primula elatior
}

\begin{tabular}{|c|c|c|c|c|c|c|c|}
\hline Managed & \multicolumn{7}{|c|}{ Abandoned } \\
\hline M1 & M2 & M3 & M4 & A1 & A2 & A3 & A4 \\
\hline
\end{tabular}

\begin{tabular}{|c|c|c|c|c|c|c|}
\hline 0 & 0 & 0 & 0 & 1 & 0 & 0 \\
\hline 0 & 0 & 0 & 0 & 1 & 0 & 0 \\
\hline 1 & 0 & 0 & 0 & 1 & 1 & 0 \\
\hline 1 & 0 & 1 & 1 & 0 & 0 & 0 \\
\hline 1 & 1 & 1 & 1 & 0 & 1 & 0 \\
\hline 1 & 1 & 1 & 1 & 1 & 0 & 1 \\
\hline 1 & 1 & 1 & 0 & 1 & 1 & 1 \\
\hline 0 & 0 & 1 & 1 & 0 & 1 & 1 \\
\hline 0 & 0 & 0 & 0 & 0 & 0 & 0 \\
\hline 0 & 0 & 0 & 0 & 0 & 1 & 0 \\
\hline 1 & 1 & 1 & 1 & 1 & 1 & 1 \\
\hline 1 & 1 & 0 & 1 & 1 & 1 & 1 \\
\hline 0 & 1 & 0 & 0 & 0 & 0 & 0 \\
\hline 0 & 0 & 0 & 1 & 0 & 0 & 0 \\
\hline 1 & 0 & 0 & 0 & 0 & 0 & 0 \\
\hline 0 & 1 & 0 & 0 & 0 & 0 & 0 \\
\hline 0 & 1 & 1 & 0 & 0 & 0 & 0 \\
\hline 1 & 1 & 0 & 1 & 1 & 0 & 0 \\
\hline 1 & 1 & 0 & 1 & 1 & 0 & 1 \\
\hline 0 & 0 & 0 & 0 & 1 & 0 & 0 \\
\hline 0 & 0 & 1 & 0 & 0 & 0 & 0 \\
\hline 0 & 0 & 1 & 0 & 0 & 0 & 0 \\
\hline 1 & 0 & 0 & 0 & 1 & 0 & 0 \\
\hline 0 & 1 & 0 & 1 & 0 & 0 & 0 \\
\hline 0 & 0 & 0 & 0 & 0 & 1 & 0 \\
\hline 0 & 0 & 0 & 0 & 0 & 0 & 1 \\
\hline 1 & 1 & 1 & 1 & 0 & 1 & 1 \\
\hline 1 & 1 & 1 & 1 & 1 & 0 & 0 \\
\hline 1 & 1 & 1 & 1 & 0 & 0 & 0 \\
\hline 1 & 1 & 1 & 1 & 1 & 1 & 1 \\
\hline 1 & 0 & 0 & 0 & 1 & 0 & 0 \\
\hline 0 & 1 & 1 & 1 & 0 & 1 & 1 \\
\hline 1 & 1 & 1 & 1 & 1 & 0 & 0 \\
\hline 1 & 1 & 1 & 1 & 0 & 0 & 0 \\
\hline 0 & 0 & 0 & 0 & 0 & 0 & 0 \\
\hline 1 & 1 & 0 & 1 & 0 & 0 & 0 \\
\hline 1 & 1 & 1 & 1 & 1 & 1 & 1 \\
\hline 0 & 1 & 0 & 0 & 0 & 0 & 0 \\
\hline 1 & 1 & 1 & 1 & 0 & 1 & 1 \\
\hline 1 & 1 & 1 & 1 & 0 & 0 & 0 \\
\hline 0 & 0 & 0 & 0 & 1 & 0 & 0 \\
\hline 0 & 0 & 0 & 0 & 0 & 0 & 1 \\
\hline 1 & 0 & 0 & 0 & 1 & 0 & 0 \\
\hline 0 & 1 & 0 & 1 & 0 & 0 & 0 \\
\hline 0 & 1 & 0 & 0 & 0 & 0 & 0 \\
\hline 0 & 0 & 0 & 0 & 1 & 0 & 0 \\
\hline 0 & 1 & 0 & 1 & 0 & 0 & 0 \\
\hline 1 & 0 & 0 & 0 & 1 & 1 & 0 \\
\hline 1 & 1 & 0 & 1 & 0 & 1 & 0 \\
\hline 1 & 1 & 1 & 1 & 1 & 0 & 1 \\
\hline 1 & 1 & 1 & 1 & 0 & 1 & 0 \\
\hline 0 & 0 & 1 & 0 & 0 & 0 & 0 \\
\hline 0 & 1 & 1 & 1 & 0 & 1 & 1 \\
\hline 0 & 1 & 0 & 1 & 0 & 0 & 0 \\
\hline 1 & 0 & 0 & 0 & 0 & 0 & 0 \\
\hline 1 & 0 & 0 & 0 & 1 & 0 & 0 \\
\hline 1 & 1 & 0 & 0 & 0 & 0 & 0 \\
\hline 0 & 0 & 0 & 0 & 1 & 0 & 0 \\
\hline 1 & 1 & 0 & 1 & 1 & 1 & 0 \\
\hline 0 & 0 & 1 & 0 & 0 & 0 & 0 \\
\hline 0 & 1 & 0 & 1 & 0 & 1 & 0 \\
\hline
\end{tabular}




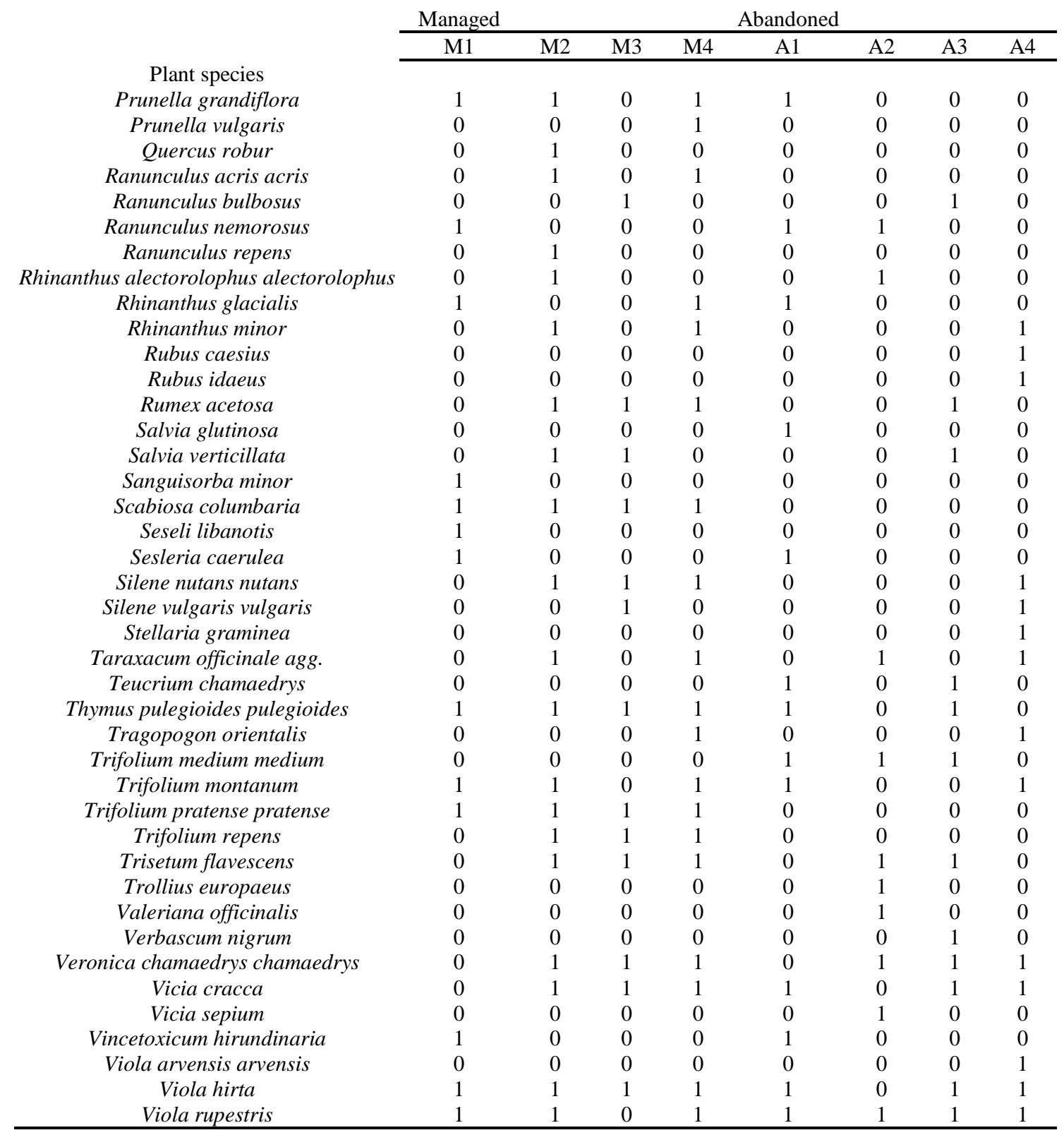

